\title{
Katarzyna Kowal*
}

Akademia im. Jana Długosza w Częstochowie

\section{W POSZUKIWANIU SIEBIE. INDYWIDUALNE MOTYWY PODWIESZANIA CIAŁA PRAKTYKOWANEGO WSPÓŁCZEŚNIE W POLSCE}

\begin{abstract}
Artykuł jest poświęcony praktyce podwieszania ciała będącej jedną z form zabawy z ciałem (body play) zainicjowanej i spopularyzowanej przez ruch Modern Primitives („współczesnych prymitywistów”). Jego empiryczną podstawę stanowią autorskie badania socjologiczne skoncentrowane wokół problematyki indywidualnych motywów praktykowania podwieszania ciała. Grupę badawczą stanowiły osoby mające za sobą wielokrotne doświadczenia z podwieszaniem własnego ciała $(N=30)$. Jako że za strategię prowadzonych badań obrano metodologię teorii ugruntowanej, w ich realizacji posłużono się techniką wywiadu swobodnego ukierunkowanego. Teoretyczną ramę analiz empirycznych wyznaczyła połączona, bo społeczno-kulturowa i zarazem jednostkowa perspektywa patrzenia na ciało, przy czym ta ostatnia - z uwagi na obraną strategię badawczą - pozostawała najważniejsza. W zgromadzonym materiale empirycznym pojawiły się następujące motywy udziału badanych w praktyce podwieszania ciała: poznanie własnego ciała; pokonanie ograniczeń ciała; realizacja prawa własności wobec ciała; praca nad ciałem; doświadczenie odmiennego stanu świadomości; osiągnięcie duchowo-cielesnej ekstazy; promocja neoprymitywistycznego nurtu podwieszania ciała. W tak przedstawionej motywacji podwieszania ciało jawi się jako źródło wiedzy i doświadczenia, miejsce kontroli, obiekt własności, źródło przyjemności, a nade wszystko centrum tożsamości.
\end{abstract}

Słowa kluczowe: socjologia ciała, podwieszanie ciała, modyfikacje ciała, motywy podwieszania ciała, tożsamość

\section{WSTĘPNE INSPIRACJE}

Podwieszanie ciała jest jedną z form body play (,zabawy z ciałem”). Pojęcie to stworzył Fakir Musafar uznawany za ojca zainicjowanego w Stanach Zjednoczonych subkulturowego ruchu Modern Primitives (,współczesnych prymitywistów”). Ruch ten powstał pod koniec lat siedemdziesiątych ubiegłego stulecia, co przypadało na czas najintensywniejszego rozkwitu body art w kulturze amerykańskiej. To właśnie założenia body art dotyczące postrzegania ciała ludzkiego neoprymitywiści włączyli do filozofii swojego ruchu. Ich sensem jest traktowanie ciała jako źródła wiedzy o sobie, w tym przede wszystkim posiadanych fizycznych i psychicznych barierach. Podkreślając w tym kluczową rolę ciała, ruch Modern Primitives skupia się wokół zjawiska jego modyfikowania, które ma być drogą prowadzącą do owego

* Adres do korespondencji: Katarzyna Kowal, Instytut Nauk Społecznych i Bezpieczeństwa w Akademii im. Jana Długosza, ul. D. Zbierskiego 2/4, Częstochowa; e-mail: k.kowal@ajd.czest.pl. 
samopoznania i umożliwiającą dokonywanie osobistych transgresji. Kontekstem czy them interpretacji znaczenia i symboliki ukrytej w wykonywanych modyfikacjach ciała stały się dla neoprymitywistów rytuały społeczności plemiennych. Czysto biologiczne czy fizjologiczne aspekty cielesności nie są bowiem dla „współczesnych prymitywistów” szczególnie istotne. Ciało interesuje ich przede wszystkim w kategoriach społecznych i kulturowych. Przez jego modyfikowanie „stawiają się oni w opozycji do społecznie akceptowanych norm i nakazów związanych $\mathrm{z}$ cielesnością, przełamują kulturowe tabu polegające na przypisywaniu ciału konkretnych właściwości i powinności, na przykład wynikających z pełnionych przez jednostkę ról płciowych" (Ciężki 2016). Wśród stosowanych przez nich modyfikacji cielesnych najbardziej typowy jest tatuaż typu tribal (plemienny), którego formy pozostają zgodne z naturalnymi konturami ciała, oraz piercing twarzy. Do bardziej radykalnych metod modyfikowania ciała przez „współczesnych prymitywistów” należy zaliczyć natomiast piętnowanie (branding), wypalanie (burning) lub wycinanie (cutting) jako najprostsze formy skaryfikacji o zdecydowanie rytualnym charakterze oraz skaryfikacje przyjmujące postać tatuaży bliznowych (Klesse 2000: 15-38). Wspólne wszystkim wymienionym modyfikacjom jest poszukiwanie w nich tych doznań i przeżyć, które miały pozwolić neoprymitywistom rozwijać własną duchowość. To, co określa przedstawicieli tego ruchu, to z pewnością kontestacja wartości współczesnej cywilizacji, swego rodzaju pogarda dla kultury masowej oraz bunt wobec przyjętych w niej kanonów estetycznych. Uważając się za propagatorów wolności cielesnej ekspresji, traktują ciało jako nośnik informacji na temat indywidualnej i społecznej tożsamości jednostki (Atkinson i Young 2001: 117-146). Słynący z zamiłowania do wielkomiejskiego stylu życia Modern Primitives od początków istnienia ruchu zamieszkiwali przede wszystkim takie metropolie, jak Los Angeles, Nowy Jork, San Francisco i Toronto. Członkowie ruchu wywodzą się z różnych środowisk społecznych, grup wiekowych, etnicznych i zawodowych, przejawiają różne orientacje seksualne.

W zakres działalności Modern Primitives wchodzi też organizacja warsztatów i szkoleń poświęconych technikom modyfikowania ciała, wśród których największą popularnością cieszą się spotkania prowadzone przez czołowego przedstawiciela ruchu - F. Musafara. Obecnie osiemdziesięciosześcioletni Amerykanin przygodę z modyfikacjami ciała zaczął w wieku trzynastu lat. Przedstawiona przez niego lista praktyk modyfikowania ciała zawiera siedem sposobów „zabawy z ciałem”, a jej autor doświadczył prawie wszystkich z nich. Według definicji Musafara (1990) sensem wymienionych poniżej praktyk typu body play ma być uzyskanie odmiennych stanów świadomości, do czego mają prowadzić następujące formy używania ciała: 1) modelowanie ciała (gimnastyka, joga, rozciąganie); 2) krępowanie ciała (bandażowanie, gorsetowanie, ściskanie); 3) deprywacja sensoryczna (głodówka, brak snu); 4) obciążanie ciała (ciężkie bransolety, łańcuchy); 5) działanie ogniem (przypalanie, gorące prysznice); 6) penetracja ciała (biczowanie, przekłuwanie, tatuowanie); 7) podwieszanie ciała (wiszenie na hakach wbitych w skórę). W stworzonym przez Musafara magazynie „Body Play and Modern Primitives Quarterly” znajdujemy definicję pojęcia body play, które należy rozumieć jako „,elowe, rytualne modyfikacje ciała ludzkiego. Jest to głęboko zakorzenione, uniwersalne pragnienie, które przekracza czasowe i kulturowe granice" (BPandMPQ 1(1): 3, za: Klesse 2000: 15-16). 


\section{POLSKA SCENA PODWIESZANIA CIAŁA ${ }^{1}$}

Początkowo odległa naszej kulturze koncepcja body play, w tym podwieszanie ciała na hakach, przeniknęła do Europy. Stało się to jednak przy pewnym oderwaniu od filozofii Modern Primitives, a bynajmniej braku bezpośrednich do niej odwołań. Na terenie Polski doszło do uformowania się kilku grup ludzi zainteresowanych popularyzowaniem tej formy zabawy z ciałem, czemu również towarzyszyło niejako jej wyalienowanie z neoprymitywistycznego kontekstu. Co roku w jednym z dużych miast (Wrocław, Warszawa, Łódź, Gdańsk, Kraków, Katowice) organizowane są konwencje body suspension, podczas których znawcy tej praktyki prezentują technikę podwieszania ciała. Ten wyraźny brak związku ze sposobem praktykowania podwieszania ciała propagowanym przez ruch Modern Primitives przejawia się choćby w tym, że żadna z tych konwencji nie odbyła się przy udziale F. Musafara, jak miało to miejsce na przykład we Włoszech czy Norwegii. Zasadnicze różnice dotyczą miejsca, w którym odbywa się podwieszanie, samego sposobu jego przeprowadzania oraz ról przypisanych poszczególnym osobom zaangażowanym w tę praktykę. I tak, seanse podwieszania ciała w Polsce odbywają się przede wszystkim w awangardowych klubach nocnych, scenach festiwali tatuażu bądź prywatnych mieszkaniach. Bardzo rzadko organizowane są natomiast podwieszenia plenerowe, na które Musafar kładzie duży nacisk podczas prowadzonych przez siebie warsztatów. Podwieszaniu ciała praktykowanemu przez grupy w Polsce brakuje rytualnej otoczki, na którą u neoprymitywistów składa się między innymi okadzanie uczestników podwieszania dymem, ograniczenie rozmów, rytmiczna muzyka grana na bębnach czy też rozpalenie w centralnym miejscu ogniska. Nie występuje też na ogół religijny synkretyzm właściwy szkole body suspension Musafara, przejawiający się choćby w odmawianiu na początku rytuału krótkiej modlitwy nawiązującej do filozofii New Age (Fenske 2007: 135-136). Innym przykładem owego synkretyzmu może być troska Musafara o właściwe rozmieszczenie w ciele haków, które oznacza każdorazowo uwzględnienie umiejscowienia w nim poszczególnych czakr. I wreszcie, w polskich seansach podwieszania brakuje prowadzącego rytuał, czyli kogoś, kto pełniłby w nawiązaniu do kultur plemiennych funkcję szamana.

To, co jeszcze określa polską scenę podwieszania, to z pewnością jej mocne sfragmentaryzowanie. I nie chodzi tu wyłącznie o liczbę grup zajmujących się podwieszaniem w Polsce ani występujące między nimi konflikty. Mowa tutaj przede wszystkim o co najmniej kilku nurtach, w których definiowane i praktykowane jest podwieszanie ciała w środowisku osób podwieszających i podwieszanych. Zdecydowanie dominującym jest wśród nich ten o charakterze performatywnym, słabo nawiązujący do spuścizny ruchu Modern Primitives. Wpływ samego F. Musafara na rozwój praktyki podwieszania w Polsce jest wpływem jedynie zapośredniczonym przez osobę Håvve Fjella. Ten norweski performer, który odegrał największą rolę w kształtowaniu polskiej sceny podwieszeniowej, jak sam przyznaje, na początku swojego zainteresowania modyfikacjami ciała wiele czerpał z lektury Modern Primitives (Vale

1 Z uwagi na pionierski charakter badań stanowiących empiryczną podstawę niniejszego tekstu pragnę zaznaczyć, że dane zawarte w niniejszym podrozdziale są autorską próbą scharakteryzowania polskiej sceny podwieszania ciała wyłącznie na podstawie zgromadzonego materiału badawczego. 
i Juno 1989). Wspomniana publikacja, uznawana w Stanach Zjednocznych za „biblię tatuażu i piercingu", nie spotkała się jednak w Polsce z szerokim zainteresowaniem, mimo że polscy piercerzy i tatuatorzy organizują seanse podwieszania jako jedną z wielu oferowanych przez siebie usług. Nie wolno też zapomnieć o komercyjnym aspekcie polskiego podwieszania performatywnego, w obliczu którego pokazy przyjmują niekiedy formułę „krwawego show” angażującego na przykład strongmenów i mają stricte wyczynowy charakter. Najmniej obecny w Polsce jest natomiast nurt podwieszania, który posiada wyraźnie neoprymitywistyczny układ odniesienia i inspirowany jest ceremoniami społeczności plemiennych. Skupiona wokół niego wąska grupa osób pragnie przywrócić podwieszaniu ciała jego rytualny i kolektywny wydźwięk.

Aktorami polskiej sceny podwieszania ciała na hakach są przede wszystkim ludzie młodzi o alternatywnych w stosunku do odbiorców kultury masowej zainteresowaniach, powiązani ze światem body modification oraz subkulturami skupionymi wokół takich stylów muzycznych, jak punk, hardcore punk czy metal. Coraz częściej organizowane pokazy podwieszania stają się dziś częścią takich imprez, jak festiwal sztuki tatuażu Tattoofest czy festiwal muzyki gotyckiej - Castle Party. Z każdym takim pokazem przybywa osób chętnych, aby podwiesić swoje ciało. To właśnie wzrastająca popularność podwieszania ciała stała się inspiracją do podjęcia przeze mnie badań socjologicznych nad tą praktyką cielesną. W wielości wątków, które wyłoniły się w tych badaniach, na osobne, wnikliwe studia zasługuje kwestia indywidualnych motywów praktykowania podwieszania ciała.

\section{NAJSTARSZE FORMY PODWIESZANIA CIAŁA}

Podwieszanie ciała na hakach korzeniami sięga plemiennych rytuałów rdzennych Indian Ameryki Północnej. Podstawą tych praktyk była silna wiara w to, że poprzez ciało można kontaktować się ze światem duchów i demonów. Najstarszą formą podwieszania ciała był rytuał zwany tańcem słońca. I choć w niektórych pracach źródłowych czytamy, że „z kultem słońca taniec ten nie miał jednak nic wspólnego" (Cyrus 1997: 53), to w innych przekonuje się, że u Indian Prerii taniec słońca był najważniejszym rytuałem bardzo istotnego w ich wierzeniach kultu słońca (Posern-Zielińscy 1977: 101, 105-106).

Wśród obrzędów Indian Ameryki Północnej, takich jak taniec wojenny, taniec skalpu czy bizona, taniec słońca był ceremonią najsłynniejszą. Tahca Ushte, czarownik Siuksów, twierdzi, że taniec słońca jest nie tylko najbardziej uroczystą, ale i najstarszą ze wszystkich indiańskich ceremonii. Poszczególne plemiona różniły się jej przebiegiem i częstotliwością: niektóre odprawiały ją bardzo rzadko, inne każdego lata (Cyrus 1997: 53). W tym ostatnim przypadku taniec słońca organizowano w czasie letniego przesilenia. Ta ogólnoplemienna uroczystość odbywała się, co bardzo ważne, tuż przed rozpoczęciem letniego sezonu polowań na bizony (Posern-Zielińscy 1977: 101).

Opisujący kulturę indiańską Jerzy Gąssowski tak charakteryzuje motywy jej samoudręczających rytuałów: „Wszędzie służyły stworzeniu odpowiednich stanów psychicznych, ułatwiających nawiązanie kontaktu z Bóstwem lub światem bytów pozazmysłowych". Był to jeden $\mathrm{z}$ wielu stosowanych przez ludy indiańskie sposobów wprowadzenia w stan halucynacji. 
Doznawane w nim wizje były tym, czemu Indianie, a zwłaszcza Indianie Prerii, przypisywali wielkie kulturowe znaczenie w swoich wierzeniach i światopoglądzie. „Wierzono, iż w czasie wizji Duch wchodzi w bezpośredni kontakt z człowiekiem, może sprawować nad nim opiekę lub udzielać mu skutecznych rad”. Ci, którzy w kulturach indiańskich ze szczególną łatwością wchodzili w stan transu i doświadczali wizji, stawali się szamanami. Warto w tym miejscu dodać, że sama treść wizji w obrębie poszczególnych plemion indiańskich znacznie się różniła. Determinowały ją zasłyszane i przekazywane w obrębie plemienia mity i opowieści. Ponieważ uzyskanie wizji dla większości tych, którzy się o to starali, było bardzo trudne, odwoływano się do osiągania ich właśnie w wyniku zadawania sobie okrutnych tortur. „Uważano bowiem, że jeśli zawiodły łagodniejsze sposoby, Duch może ulitować się nad straszliwie udręczonym młodzieńcem i udzielić mu upragnionej wizji” (Gąssowski 1996: 162-163).

Warunkiem udziału w rytuale tańca słońca było odbycie postu i oczyszczenie się w saunie. Zgodnie z opisem przebiegu tańca, ci uczestnicy rytuału, którzy decydowali się na samookaleczenie, przywiązywali się rzemieniami lub linami do ustawionego w centralnym miejscu pala. Uprzednio jednak na skórze ich piersi wykonywane były nacięcia, w których umocowywano liny za pomocą małych drewnianych kołków. Sam taniec polegał na krążeniu wokół pala z twarzą zwróconą ku jego czubkowi, czemu towarzyszyły rytmiczne odgłosy bębnów (Cyrus 1997: 53). Pal jako ,święty słup” uważany był przez niektóre plemiona północnoamerykańskich Indian za „drogę, po której modlitwy podążają do Nieba” (Eliade 1997: 110). Zgodnie z tym, co pisze Zbigniew Teplicki, taniec trwał ,aż do stanu ekstazy i do wykrwawienia się lub oderwania płata żywego mięśnia” (1994: 300). Podobnie jego finalny moment przedstawia Irene Salome Cyrus: „,[...] tancerz tańczył przez cały dzień, aż w końcu wpadał w trans i bez przytomności, przeważnie zalany krwią, walił się na ziemię" (1997: 53). Ów końcowy akt tańca słońca u Mandanów nazywany był „ostatnim wyścigiem” (PosernZielińscy 1977: 106). Taniec słońca u Czejenów przebiegał według nieco innego scenariusza mityczno-rytualnego. Po wbiciu w piersi tancerza drewnianych kołków przywiązywano do nich sznury przymocowane wcześniej do pala. Następnie przebite ciało podciągano na linach do góry. „Tak uwiązani zwisali całym ciężarem ciała przez długie godziny, szarpiąc nim dla większego bólu, aż do pojawienia się upragnionej wizji” (Gąssowski 1996: 163). Doznanie przez tancerza szczęśliwej wizji oznaczało, że zjednał on sobie Ducha Strażnika, dzięki czemu mógł czuć się bezpieczny już do końca swojego życia. Wizje wypełniały bowiem nakazy dotyczące na przykład tego, co Indianin powinien nosić w kultowym woreczku na fetysze. Ci, którzy doświadczali w trakcie swojej wizji większej łaski, otrzymywali w darze szczególną pieśń. Jeśli tylko znaleźli się w potrzebie i zanucili ją, Duch Strażnik przychodził im z pomocą (Gąssowski 1996: 162).

Taniec słońca jest jednym $\mathrm{z}$ tych dawnych rytuałów, które choć w zmodyfikowanej formie, to jednak przetrwały do dziś. Mimo kilkudziesięciu lat, w trakcie których obowiązywał wprowadzony w roku 1881 zakaz wykonywania tego rytuału, znów traktowany jest on jako centralna uroczystość religijna. „Taniec Słońca - jak twierdzą Mirosława i Aleksander Posern-Zielińscy - nie odrodził się jednak w pełni w swym pierwotnym kształcie”. Z ceremonii wyeliminowano przede wszystkim te wątki, które polegały na ofiarnych torturach. Sam scenariusz również uległ znaczącym modyfikacjom, wskutek których rytuał ten został uproszczony. Współcześnie mają w nim uczestniczyć, obok tubylczej ludności, ci Indianie, 
którzy choć na co dzień są uczestnikami kultury społeczeństwa amerykańskiego, to jednak w dalszym ciągu podzielają autochtoniczne wartości Indian. Co stanowi o motywach udziału we współczesnym tańcu słońca? Zaangażowanie w tę ceremonię ma wynikać z pragnienia podtrzymywania i kultywowania więzi z tradycją, ma być swego rodzaju przeciwstawieniem się uniformizującemu działaniu kultury białego człowieka Ameryki. Wierzenia i praktyki religijne Indian, choć wyraźnie nawiązują do minionej w sposób bezpowrotny przeszłości, to utraciły swoje dawne funkcje. Jak czytamy w literaturze przedmiotu, ,[...] poczęły one odgrywać rolę opoki, na której - w przeświadczeniu Indian - odrodzi się indiańska kultura dostosowana do wymogów współczesnego życia” (Posern-Zielińscy 1977: 111).

\section{PROBLEMATYKA I METODA BADAŃ}

Jako że główny problem badawczy, wokół którego koncentrowały się moje badania, dotyczył istoty współczesnego podwieszania ciała, $\mathrm{w}$ jednym z uszczegóławiających jego zakres pytań chodziło o poznanie indywidualnych motywów skłaniających do udziału w tej praktyce cielesnej. Badaniami socjologicznymi objęto osoby praktykujące podwieszanie ciała na hakach, które zgodnie z celowym doborem próby były podwieszane zarówno w trakcie kameralnych spotkań bez udziału publiczności, jak i podczas otwartych konwentów. Prezentowany w niniejszej pracy materiał empiryczny stanowi część większego projektu badawczego poświęconego praktyce podwieszania ciała. Z uwagi na ograniczenia objętościowe tekstu skoncentruję się na danych zgromadzonych wyłącznie podczas badania osób, które mają za sobą wielokrotne doświadczenia z podwieszaniem własnego ciała $(N=30)$. Dopełniając tej charakterystyki, warto dodać, że osoby objęte badaniem okazały się w znacznym stopniu zmodyfikowane cieleśnie. Do posiadanych przez badanych modyfikacji ciała, nierzadko trwale zmieniających ich wygląd, należy przede wszystkim zaliczyć piercing takich miejsc jak uszy, nos, wargi, brwi, policzki, język, sutki, pępek i narządy płciowe, liczne tatuaże i skaryfikacje (tatuaże bliznowe), implanty podskórne, rozciągnięcia płatków usznych, a także rozszczepienie języka.

Na podstawie zgromadzonego materiału empirycznego udało się również nakreślić socjodemograficzny portret badanych. Cechy konstytuujące ten obraz to brak wyraźnej dominacji określonej płci. Badani są ludźmi młodymi, mieszczącymi się w przedziale wiekowym 21-28 lat. Na ogół są to osoby studiujące bądź posiadające już wyższe wykształcenie. Zamieszkują miasta liczące powyżej 100 tysięcy mieszkańców. Co się tyczy ich stanu cywilnego, to żaden z badanych nie pozostawał w związku małżeńskim, jakkolwiek większość żyła w heteroseksualnych związkach partnerskich. Niektórzy deklarowali powiązania z kulturą hardcore punk lub punk. Znamienna i zdecydowanie dominująca jest natomiast cecha dotycząca areligijności badanych.

Zgodnie z założeniami metodologii teorii ugruntowanej, obranej jako strategia prowadzonych badań jakościowych, w realizacji badania sięgnięto po technikę wywiadu swobodnego ukierunkowanego, w którego przeprowadzeniu posłużono się dyspozycjami. Przyjęły one postać listy potrzeb informacyjnych badaczki, która została sformułowana dość ogólnie, tak aby osoba przeprowadzająca wywiad (każdorazowo była to autorka tekstu) mogła zachować swobodę $\mathrm{w}$ formułowaniu pytań. Same pytania odnosiły się do zagadnień szczegółowych związanych z praktykowaniem podwieszania ciała i oprócz motywów dotyczyły również 
techniki podwieszania, doświadczanych doznań i wrażeń, znaczenia przypisywanego tej praktyce, reakcji społecznych na podwieszanie, relacji ze środowiskiem osób podwieszających i podwieszanych oraz planów związanych z podwieszaniem własnego ciała. Wszystkie pytania miały charakter otwarty. W sytuacji gdy ogólnie sformułowane dyspozycje nie dawały oczekiwanego rezultatu, korzystano z przygotowanych wzorów konkretnych pytań. Zapis uzyskanych informacji polegał na dokładnej rejestracji wypowiedzi badanych. Przeprowadzenie wywiadów wiązało się z fizycznym dotarciem do każdego z badanych. Czas trwania wywiadu wahał się w granicach 120-150 minut. Uzyskany w badaniu systematycznie zbierany, bardzo obszerny materiał empiryczny został poddany transkrypcji. Następująca po nich faza konceptualizacji materiału jakościowego polegała na rzeczowym kodowaniu danych (najpierw otwartym, a następnie selektywnym), w trakcie którego badaczka starała się nie zamykać na pojawiające się nowe wątki w badaniu. Chodziło tutaj o właściwe metodologii teorii ugruntowanej podtrzymywanie w badaniu tzw. „kontekstu odkrycia (serendipity)”, gdyż to właśnie „dzięki jej procedurom mamy zdolność poszukiwania i odkrywania zjawisk, których na początku badań nie szukaliśmy” (Konecki 2000: 27). W następnych etapach analizy tak uporządkowanych danych empirycznych dokonano wypreparowania kategorii będących zespołami wcześniej utworzonych kodów, skonceptualizowania własności tych kategorii oraz odkrycia powiązań występujących pomiędzy nimi. Jedną z takich kategorii, która stała się centralnym pojęciem analizy na potrzeby niniejszego tekstu, okazały się „motywy podwieszania ciała". Pragnę w tym miejscu zaznaczyć, że zbieranie danych i ich analiza stale pozostawały czynnościami wzajemnie się przeplatającymi i w żadnym momencie badania nie zostały rozdzielone. Jako że generowanie teorii na podstawie metodologii teorii ugruntowanej jest procedurą długotrwałą, zbieranie danych zostało podporządkowane wymogom procesu teoretycznego pobierania próbek (theoretical sampling) z wykorzystaniem metody „permanentnej analizy porównawczej” (constant comparative method) aż do teoretycznego nasycenia danych (Konecki 2000: 31).

\section{TEORETYCZNE RAMY ANALIZ EMPIRYCZNYCH}

Przyjęcie za strategię analityczną metodologii teorii ugruntowanej oznacza, że głos w interpretacji sensu współczesnej praktyki podwieszania ciała został oddany zaangażowanym w nią aktorom. Daje to możliwość pełnego wyjaśnienia i zrozumienia indywidualnych motywów podwieszania ciała będących przedmiotem poniższych analiz, unikając przy tym fałszowania wyników przez samopotwierdzające się teorie. Nie zmienia to jednak faktu, że w końcowej fazie analizy materiału empirycznego odnajdywałam jego istotne powiązania z koncepcjami cielesności proponowanymi przez systemy teoretyczne z obszaru nie tylko samej socjologii ciała, ale socjologii w ogóle. Co ważne, właściwe tym koncepcjom pojęcia znalazły wyraźne odniesienie w zebranych przeze mnie danych empirycznych. Ograniczając jednak mogące się tutaj pojawić prekonceptualizacyjne zapędy, starałam się, aby określony sposób teoretyzowania ciała pozostawał wyłącznie ramą dla moich interpretacji.

Przede wszystkim stanowić ją będzie teoria strukturacji Anthony’ego Giddensa, której sensem jest analiza statusu ucieleśnionego podmiotu. Jedno z najistotniejszych z nią powiązań 
dotyczy eksponowanej przez A. Giddensa (2012) refleksyjności ciała, której trudno nie dostrzec u badanych, a która przekłada się na ich kolejne tożsamościowe zmiany. To właśnie refleksyjność doświadczenia cielesnego w podwieszaniu jest tym, co odróżnia jego współczesne praktykowanie od tego, które właściwe było rytualnym ceremoniom społeczeństw tradycyjnych. Badani w sposób niezwykle wyraźny wpisują się w panującą w nowoczesności tendencję do coraz ściślejszego wiązania tożsamości z ciałem, co Giddens nazywa ucieleśnieniem ,ja” (2012: 86). „Nowoczesność - jak pisze autor - radykalnie przekształca charakter życia codziennego i zmienia najbardziej osobiste doświadczenia człowieka. Nowoczesność należy rozważać na poziomie instytucjonalnym, ale transmutacje zachodzące na tym poziomie znajdują bezpośrednie przełożenie na życie jednostek i, co za tym idzie, ich tożsamość" (Giddens 2012: 11). A zatem w wielu miejscach poniższych analiz ujawni się Giddensowska wizja ciała jako głównego elementu refleksyjnego projektu jednostki.

Kolejne dostrzeżone przeze mnie w końcowej fazie analizy materiału empirycznego powiązania dotyczą poglądów zarówno naturalistów, jak i konstruktywistów społecznych. Uciekając jednak od właściwych im ograniczeń wynikających z redukcjonistycznych tendencji, zdefiniowałam ciało jako byt nieukończony, biologiczny i społeczny zarazem, w czym z kolei pozostaję zgodna z Chrisem Shillingiem (2010). I tak, mimo osadzenia analiz empirycznych w społeczno-kulturowych realiach (po)nowoczesności, nie zamierzam ignorować ciała materialnego, które nie tylko podlega kształtowaniu przez wpływy społeczeństwa, ale i samo to społeczeństwo kształtuje. Jak pisze Ch. Shilling, „Ciało stanowi nieredukowalne źródło społeczeństwa: to własności i umiejętności ucieleśnionych istot ludzkich dostarczają korporalnych podstaw utrwalania oraz zmiany relacji społecznych i tożsamości” (Shilling 2010: 252). Materialna perspektywa ciała jest zgodna z percepcją badanych, którzy przeżywają, doświadczają i postrzegają je przede wszystkim jako fizyczny obiekt składający się z krwi, mięśni, kości i zmysłów. I choć perspektywa indywidualnego ciała traktowanego jako realny byt jest $\mathrm{w}$ poniższych analizach dominująca, to w niektórych momentach dostrzec można jego naznaczenie strukturą, kulturą, dyskursem i relacjami społecznymi. Dlatego nie sposób nie zauważyć powiązania niektórych wątków analiz z kolejną koncepcją teoretyczną. Mowa o teorii problemów działania Arthura W. Franka, zgodnie z którą ciało jest zarazem społeczne i korporalne (1991). Wskazana koncepcja pomogła mi uchronić się przed zbyt szybkim przechodzeniem od właściwej autorom społecznego konstruktywizmu perspektywy i kategorii makrospołecznych do poziomu przeżyć jednostki. A.W. Frank jest bowiem jedynym przedstawicielem tego nurtu teoretycznego, który zajmuje się przeżywaniem ciała przez człowieka. Jego koncepcja obrazuje problemy wynikające z ucieleśnienia z perspektywy jednostki, a nie systemu społecznego. I znów, koncentrując się na materialnych aspektach ludzkiej fizyczności, nie zamierzam doświadczania ich traktować jako ściśle odrębnego pola wyizolowanego od szerszych społeczno-kulturowych uwarunkowań. Według Shillinga, ,ciało fizyczne jest zarówno źródłem tożsamości (obejmując doświadczenia, uczucia i percepcje), jak i miejscem, w którym lokują się społeczne wpływy (normy grupowe przenikające poczucie tożsamości jednostki i jej ocenę tej tożsamości)" (2010: 242). Podwieszanie możemy zatem traktować jako wynik pewnych zmian i procesów społecznych, ale należy przy tym pamiętać, że uczestniczący w tej praktyce pozostają bytami wcielonymi, fizycznymi i biologicznymi. Zgromadzone dane empiryczne, w wyniku nieustannego stykania się w nich ciała jako bytu biologicznego z ciałem 
jako bytem społecznym, potwierdzają słuszność wszystkich tych działań, które mają zmierzać do budowania mostów między naturalistycznymi i konstruktywistycznymi koncepcjami ciała.

Badania, których celem było poznanie istoty współczesnych praktyk podwieszania ciała, wpisują się w ten nurt badań socjologicznych, który prowadzi do umocnienia statusu ciała w socjologii. Jest to szczególnie ważne w odniesieniu do sytuacji dość długiej nieobecności ciała w socjologii, co należy rozumieć jako wypracowanie przez socjologię „odcieleśnionego” podejścia do przedmiotu swoich badań. Faktem jest, że ciało we współczesnej socjologii stale zajmuje dość niepewne miejsce. „Pomimo rosnącego zainteresowania socjologią ciała, [...] nie jest ona w Polsce traktowana jako istotna subdyscyplina naukowa" (Jakubowska 2009: 140). Opisując podwieszanie ciała jako jedną ze współczesnych rozlicznych form i możliwości jego modyfikowania, przedstawiam je nie tylko jako interesujący aspekt ponowoczesnej rzeczywistości, ale nade wszystko wskaźnik określonego typu przemian społeczno-kulturowych. W ten sposób pragnę uwypuklić istotną rolę, jaką odgrywa ciało we współczesnym społeczeństwie. Niniejsze badania, choć pokazują tylko niektóre konteksty tych przemian, mają zaakcentować potrzebę wypracowania właściwego podejścia do konceptualizowania ciała, wzmocnienia jego statusu społecznego i związku ze społeczeństwem.

\section{CIAŁO JAKO OBIEKT POZNAWALNY}

W motywacji osób praktykujących podwieszanie ciała odnajdujemy przede wszystkim wątek poznawczy. Wyraża go chęć poznania samego doświadczenia bycia podwieszonym na hakach za skórę, wobec którego badani ujawniali swoją ciekawość. Motyw ten towarzyszył im zwłaszcza w inicjacyjnej praktyce podwieszenia:

Za pierwszym razem była to czysta ciekawość. Chciałam czysto empirycznie podejść do tego i sprawdzić to na własnej skórze (K, 25 lat).

Ten najważniejszy motyw to ciekawość. To kolejne doświadczenie do kolekcji. Staram się przeżywać różne rzeczy. To była możliwość poznania czegoś, czego do tej pory nie miałem okazji poznać (M, 23 lata).

Podwieszam się, bo jestem ciekaw takiego doświadczenia. Jestem ciekaw, co to doświadczenie może mi dać (M, 23 lata).

Podwieszanie ma dostarczyć badanym wiedzy o możliwościach własnego ciała, w tym przede wszystkim progu jego wytrzymałości bólowej. To swoisty test ciała, jeden z wielu sprawdzianów, którym jest ono poddawane. W tym kontekście motywacji badanych podwieszanie stanowi element nauki własnego ciała. Poznanie go oznacza dla nich pogłębienie relacji ciało-umysł w odniesieniu do tego, w jaki sposób badanym udało się ukształtować tę relację w wyniku wcześniejszych modyfikacji i praktyk cielesnych:

W podwieszaniu poszukiwałam jakichś takich możliwości ciała, zdolności, jakichś granic, co mogę, a czego nie mogę. Na ile moje ciało jest w stanie mi na coś pozwolić? Czy w ogóle dam 
radę posiedzieć z wbitym hakiem, czy dam radę się podwiesić, czy to w ogóle mi się uda? Czy na przykład zemdleję, bo tego też nie wiedziałam... A tak się mogło zdarzyć! Czy uda mi się wisieć minutę, pięć czy godzinę? Także... trochę próba sił (K, 23 lata).

To była chęć spróbowania czegoś nowego, tylko i wyłącznie. Tak jak większość modyfikacji ciała jest dokumentowana przez ludzi jako chęć zmiany wizerunku, no to suspension jednak nic takiego wizualnego w życie nie wnosi. Daje po prostu... pokazuje, jak duże możliwości ma nasz umysł i nasze ciało, że jesteśmy w stanie pogodzić jedno z drugim (K, 21 lat).

Motywem podwieszania nie jest natomiast chęć przeżywania bólu jako takiego. Badani poprzez praktykowanie podwieszania ciała uczą się panować nad bólem i przejmować za niego odpowiedzialność, przy jednoczesnym jednak uznaniu go, podobnie jak blizn po podwieszeniu, za skutek uboczny tej praktyki cielesnej. Motywacji badanych w żaden sposób nie można przypisać charakteru autodestrukcyjnego, wszak na co dzień dbają o swoje ciała i utrzymują je w dobrej kondycji. Upiększają je tatuażami, bo chcą być zadowoleni z tego, jakie wrażenia ich ciała wywołują u innych ludzi. Dlatego każdorazowo zastanawiają się nad konsekwencjami podwieszenia dla wizerunku swojego ciała. I tak na przykład dostrzegalna jest troska o nie w trakcie czynności poprzedzających samo podwieszanie. Jej wyrazem ma być dopilnowanie, by haki były tak rozmieszczone na ciele, aby estetycznie wkomponowywały się we wzór posiadanych już tatuaży i w żaden sposób nie zaburzały ich kształtu. W podwieszaniu nie chodzi zatem o wyrażenie nienawiści do ciała. Skoro badani uważają swoją cielesność za istotną, chcą dowiedzieć się więcej nie tylko o związanych z nią możliwościach, ale i ograniczeniach. Zrozumienie tego motywu mogłoby sprawić, że podwieszanie ciała przestanie być postrzegane jako stojące w kontraście do współczesnych praktyk estetyzowania i troski o ciało. Póki co, wywołuje skrajne reakcje otoczenia społecznego i postrzegane jest przede wszystkim jako przejaw negacji ciała. Ci, którym badani w zaufaniu pokazali blizny po podwieszeniu, reagowali przerażeniem i wykazywali postawę stygmatyzującą podwieszanych jako osoby niezrównoważone emocjonalnie, nieobliczalne i przez to wzbudzające lęk. Nader często podzielenie się wrażeniami z tej praktyki cielesnej uruchamia wygłaszanie kierowanych pod ich adresem sądów moralnych. Sami badani przyznają, że w swoich środowiskach uchodzą za autodestrukcyjnych dziwaków, co nie może pozostawać bez znaczenia nie tylko dla indywidualnej, ale i społecznej tożsamości badanych. W czasach późnej nowoczesności, w których w sposób bezprecedensowy ludzie dbają o swoje ciała, podwieszanie ciała na hakach jest definiowane po prostu jako jego okaleczanie. Jak zauważa Ch. Shilling, „nowoczesny świat promuje i nagradza działania celowo-racjonalne" (2010: 221), a podwieszanie ciała ma być obu tych cech pozbawione. Świadoma refleksja nad własnym ciałem, a nie wyłącznie koncentracja na czymś zewnętrznym wobec ciała jest tym, co trudno zrozumieć osobom z otoczenia badanych. A ci raczej skłonni są postrzegać podwieszanie jako wynik choroby psychicznej lub rodzaj perwersji. Niektórzy posuwają się do stawiania terapeutycznych diagnoz, w których podwieszanie ciała definiowane jest przede wszystkim jako zachowanie autoagresywne, bo polegające przecież na samookaleczeniu. W bardziej empatycznych interpretacjach osoby praktykujące podwieszanie ciała postrzegane są jako mające problemy z akceptacją siebie bądź nieprzystosowane społecznie. 
Badani mają przekonanie, że wraz z kolejnymi podwieszeniami ich wiedza o własnym ciele będzie stopniowo wzrastać. Ciało postrzegają wszak jako całkowicie poznawalny obiekt. Granice tego poznania w miarę podejmowania kolejnych modyfikacji i praktyk cielesnych ulegają przesunięciu, co jest równoznaczne z przejmowaniem przez badanych coraz większej władzy nad ciałem.

\section{POKONANIE OGRANICZEŃ CIAŁA}

Mimo zasadniczych zmian w spojrzeniu na ciało, jakie wniosła nowoczesność, ciągle pozostaje ono źródłem słabości i cierpienia. Z tej świadomości bierze się kolejny rodzaj motywacji badanych, którzy upatrują w podwieszaniu ciała szansy na pokonanie jego barier, a także wewnętrznych słabości i lęków. Francuski socjolog Jean Baudrillard twierdzi, że koncentrując się na ciele w ponowoczesnej kulturze, nie tyle zmierzamy do traktowania własnego ciała jako narzędzia przyjemności, ile raczej ujawniamy nasze obawy przed jego słabością (2011: 45-46). Z kolei Zygmunt Bauman, pisząc o „ucieczce przed cielesną śmiertelnością”, twierdzi, że chodzi w niej o ,zuchwałe zanegowanie ograniczoności ciała poprzez skuteczne pokonywanie jego obecnie napotkanych, poszczególnych ograniczeń" (1998: 40). Jednym z nich jest bez wątpienia ból, który stanowi rzeczywiste ograniczenie tego, w jaki sposób badani chcą rekonstruować swoje ciała. Opór, jaki w ten sposób stawia, stoi na przeszkodzie ich pracy nad ciałem, której sensem ma być jego przekształcenie zgodnie z tożsamością właściciela. A.W. Frank twierdzi, że warunkiem rozwoju ,ja” jest świadome siebie ciało. Wtórując w tej kwestii George’owi H. Meadowi, pisze, że ciało pozostaje najbardziej świadome siebie właśnie w sytuacji napotkanego w działaniu oporu (1991: 51). Skoro ograniczeniem ciała jest to, że nie można go unieść do góry, w trakcie praktyki podwieszania w pewnym sensie zostaje ono pokonane. Najważniejszy jest tutaj bowiem lot i to, że następuje oderwanie człowieka od ziemi. To właśnie w tym kontekście, a nie zmiany kształtu i wyglądu ciała, można mówić o podwieszaniu jako formie jego przekształcania, a ściślej modyfikacji cielesnych funkcji. Zawiśnięcie ciała w górze nie jest wszak jego naturalną pozycją. To pierwsze i najważniejsze ograniczenie ciała, które badani chcą przezwyciężyć w akcie podwieszania:

Chciałem po prostu choć na chwilkę oderwać się od ziemi, żeby... żeby sprawdzić, czy potrafię i czy w tym momencie nagle poczuję się inaczej (M, 23 lata).

Chciałam jak najszybciej być w powietrzu, oderwać się od ziemi. Skupiłam się chyba na tym, żeby po prostu jak najbardziej się rozluźnić, jak najbardziej swobodnie oddychać i tyle. I po prostu czekałam na to, co się stanie. Najgorszym momentem jest moment, kiedy już człowiek stoi i jest na tej granicy, kiedy odrywa się stopami od ziemi (K, 25 lat).

Po oderwaniu stóp od podłoża podwieszanym przychodzi zmierzyć się z kolejnym oporem, jaki stawia ciało. Dlatego następny rodzaj motywacji badanych wiąże się z chęcią osiągnięcia takiego poziomu kontroli w relacji ciało-umysł, który pozwoliłby zapanować im nad własnymi ograniczeniami fizycznymi: 
Dla mnie to była taka potrzeba przełamania swojego ciała. Ja jestem osobą, która ma bardzo niski próg bólu i wszystkie modyfikacje są po prostu dla mnie bardzo bolesne. I zastanawiałam się, czy jestem w stanie poza ten ból akurat w przypadku podwieszania wyjść. I to była taka główna przyczyna, taka chęć sprawdzenia siebie (K, 28 lat).

Zrobiłam to, żeby też w jakiś sposób siebie sprawdzić. Tak, to była chęć sprawdzenia, na ile moje ciało jest w stanie wytrzymać ból. Bo jak robiłam sobie tatuaże, to już wiedziałam, jaki to jest rodzaj bólu i dlatego chciałam sprawdzić, co jeszcze mogę wytrzymać i co to jest podwieszanie (K, 25 lat).

Chciałam zobaczyć, w jakim jestem stanie z kontrolowaniem swojej psychiki, na ile ją potrafię wyłączyć, że nie odczuwam bólu, czy on jest odczuwalny w takim czy w innym stopniu (K, 25 lat).

Wykształcenie umiejętności radzenia sobie z bólem ma być tym zasobem, z którym badani chcieliby przystąpić do kolejnych podwieszeń. Przyjmą one postać swego rodzaju cielesnych eksperymentów. $Z$ reguły polegać one będą na modyfikowaniu techniki podwieszania ${ }^{2}$ przez aplikowanie w tkankę skórną zwiększonej liczby haków bądź obciążaniu podwieszonego ciała przedmiotami lub innymi osobami. W motywacji badanych dość wyraźnie rysuje się pragnienie dalszych osiągnięć związanych z przekraczaniem granic wytrzymałości bólowej, co oznacza w pewnym sensie wzniesienie się ponad swoją cielesność. O motywach przejęcia władzy nad swoim ciałem traktuje poniższa wypowiedź jednej z podwieszanych osób:

U mnie to jest głównie pokonywanie słabości. Zaplanowałem teraz takie podwieszenie... bo ja potrzebuję jakichś konkretów, żeby pokonać te wyzwania. To taka walka z ciałem. Teraz chcę zrobić coś dużo, dużo trudniejszego. Do tego podwieszania są potrzebne jakby dwa systemy tych bloczków, z dwóch stron, w ten sposób... [tu respondent demonstruje - przyp. K.K.]. Na jednych bloczkach będę zawieszony za plecy tak standardowo - cztery haki, drugie bloczki będą tutaj za kolana, też po dwa haki w kolanach, więc będę wisiał w miarę poziomo. Te liny będą w ten sposób... [tu respondent demonstruje - przyp. K.K.] i ja będę pośrodku. I jeszcze chcę to podwieszenie urozmaicić tym, że będę miał dwa haki w udach i dwa haki w dole pleców. Te dwa haki w udach i plecach będą połączone linką i na tej lince, to jest dość długa lina, będzie położona na przykład deskorolka i ktoś jeszcze na to usiądzie w formie huśtawki (M, 23 lata).

W owej walce, jaką badani w akcie podwieszania toczą ze swoimi ciałami, obecna jest motywacja pobicia rekordu czasu podwieszenia, liczby haków, na których zawiśnie podwieszany, czy dociążenia osoby podwieszanej. Badani w swoim zaabsorbowaniu cielesnością dostrzegają i wykorzystują nieograniczone możliwości modyfikowania samego aktu wiszenia na hakach wbitych w ciało. Wiele jest w tym opisie cech właściwych dla komunikatywnego typu obchodzenia się z ciałem autorstwa A.W. Franka. Mam tutaj na uwadze przede wszystkim o wiele ściślejsze wiązanie ciała z przyszłością aniżeli teraźniejszością, jego ciągłe stawanie

2 Co się tyczy technicznej strony praktyki podwieszania ciała na hakach, to angażuje ona specjalistów zajmujących się na co dzień wykonywaniem różnych form modyfikacji ciała, w tym przede wszystkim piercerów i tatuatorów. Suspension wymaga bowiem wiedzy z zakresu anatomii i fizjologii, która jest niezbędna do przekłuwania powłok skórnych. Liczba haków zależy od pozycji podwieszenia, a więc miejsca, za które osoba jest podwieszana, oraz jej wagi. Jednorazowo w ciało może zostać wbitych od kilku do kilkunastu haków, które zostają połączone ze sobą za pomocą linek wykorzystywanych w alpinistyce. 
się, nieproblematyczną przypadkowość oraz stale wytwarzane pragnienie ekspresji (1991: 89). Posiadana przez nich koncepcja ciała jest nieustannie rewidowana wraz z pojawieniem się informacji o nowych możliwościach praktyk i modyfikacji cielesnych. Taka informacja staje się dla nich sygnałem o zmieniających się granicach ciała i pokonaniu jego kolejnych ograniczeń. Przykładem może być podwieszenie się za tę część ciała, za którą nikt jeszcze nie odważył się podwiesić. Do niedawna osobom to praktykującym wydawało się niemożliwe podwieszenie ciała na hakach rozmieszczonych wyłącznie w obrębie twarzy. Ta ekstremalna figura podwieszenia została jednak zrealizowana przez dobrze znanego w Polsce performera z Oslo - H. Fjella, który nie upowszechnił jednak techniki jej wykonania, a wręcz zastrzegł, że prawo do jej stosowania przysługuje tylko jemu samemu ${ }^{3}$. Dla badanych jednak ten pojedynczy akt podwieszenia ciała „za twarz” wystarczył do tego, by uznać, że wszystkie granice stawiane przez podwieszane ciało zostały skutecznie pokonane.

Dokonanie tej transgresji jest też postrzegane w kategoriach triumfu umysłu nad cielesnością. Stąd doświadczane przez badanych poczucie niebotycznej siły i kontroli nad własnym ciałem. Projekt ciała, jaki badani posiadają w kontekście praktykowania jego podwieszania, pozostaje stale otwarty. Wpisują się w niego kolejne próby pokonywania ciała, co do których osobom podwieszanym trudno jest wskazać moment graniczny, równoznaczny z zamknięciem owego projektu. Jak zauważa Ch. Shilling, nowoczesnym jednostkom „brakuje ostatecznych kryteriów określających, jak powinno się traktować ciało" (2010: 21). Coraz większe kontrolowanie ograniczeń ciała miesza się jednak z wyczuwalną u badanych niepewnością związaną z próbą określenia jego ostatecznej formy, kształtu, wyglądu i możliwości. W owej niepewności, po zrewidowaniu swojej dotychczasowej koncepcji ciała, badani deklarują gotowość sięgnięcia po nowe i jeszcze bardziej ekstrawaganckie i tak ekstremalne modyfikacje, jak na przykład tatuaż gałek ocznych, rozciąganie sutków, warg sromowych czy worka mosznowego, a nawet amputacje niektórych części ciała. To, co upoważnia badanych do takich planów wobec swojego ciała, jest posiadane względem niego niezbywalne prawo własności. To prawo, według badanych, nie może być przez nikogo ograniczane.

\section{REALIZACJA PRAWA WŁASNOŚCI WOBEC CIAŁA}

Kolejnym zatem przejawem władzy nad ciałem, mocno zaakcentowanej w motywacyjnym kontekście podwieszania, ma być u badanych samodzielność w podejmowaniu decyzji w kwestiach z nim związanych. W ciele, a ściślej w przekształceniach jego obrazu i funkcji, urzeczywistnia się wola badanych. Ciało jest dla nich obiektem własności. Praktykowanie jego podwieszania badani uznają za swoją prywatną sprawę i element obranego stylu życia. Jeśli ma to być przejaw ich jednostkowej wolności, sami chcą decydować o momencie inicjacyjnego podwieszenia, sami wybierają pozycję, w której zawisną na hakach. „Masz ciało, to masz wybór” - mówili badani. Te autonomiczne decyzje wpisują się w proces konstruowania ucieleśnionej tożsamości, którą poprzez kolejne cielesne wybory badani będą pragnęli podtrzymywać. Chodzi tutaj nie tylko o bycie ciałem, ale także całkowite posiadanie ciała, które pozwala czynić z niego

\footnotetext{
3 Informacje uzyskane w trakcie wywiadów pogłębionych z performerami sztuki podwieszania.
} 
instrumentalny użytek. Jak pisze Georg Simmel, ciało „stanowi naszą pierwotną i niezaprzeczalną własność" (1975: 430). Ciało, które jest obiektem świadomego posiadania przez badanych, musi być interpretowane jako ciało spersonalizowane. Wobec przedstawionej powyżej interpretacji, podwieszanie ciała można uznać za formę zarządzania ciałem jako prywatnym zasobem:

Sama podejmowałam tę decyzję. Byłam pierwszy raz podwieszana na pierwszym ogólnopolskim suspension w 2007 roku i póki co jestem jedyną osobą w Polsce, która została podwieszona jako osoba niepełnoletnia. Jakbym powiedziała: „Mamo wbiją mi haki w plecy i będę sobie wisieć za skórę", to myślę, że nie byłaby zadowolona. Ja miałam wtedy niepełne 17 lat. Bo to jest moje ciało i nikt nie może o tym decydować oprócz mnie. To jest jakby... integralna część mnie. Moje ciało jest po prostu moje i tyle (K, 21 lat).

To była całkowicie samodzielna decyzja, bo to było dla mnie. Modyfikacje ciała ja już zaczęłam w gimnazjum. Zawsze czekałam na... bo była rozmowa z rodzicami, że jak będę mieć 18 lat, to mogę sobie zrobić tatuaż, mogę sobie robić, co chcę ze swoim ciałem, to są moje decyzje. Jak miałam 18 lat, to już był pierwszy tatuaż. Na konwencje to zaczęłam już jeździć w liceum, czy nawet w gimnazjum byłam już na pierwszej konwencji tatuażu w Niemczech. Podwieszanie to był kolejny etap tego, co ja już robiłam ze swoim ciałem. Robię z nim, co mi się żywnie podoba i to, co przychodzi mi do głowy. Ciało należy do mnie, ja w nim żyję (K, 25 lat).

Badani w swoich wypowiedziach odwoływali się do kwestii możliwości i wolności wyboru jako tych czynników, które kształtują ich podmiotowość. Małgorzata Jacyno pisze w tym kontekście, że „sprawczość, autentyczność, poczucie godności i wolności - główne wartości kultury indywidualizmu - urzeczywistniają się właśnie w możliwości dokonywania wyborów czy też w możliwości takiej interpretacji doświadczenia biograficznego, która pozwala je doświadczać jako efekt wykonywania wyborów” (2007: 23). To właśnie podmiotowość i sprawstwo są tymi wartościami, które ukierunkowują możliwości i umiejętności przekształcania własnej cielesności u badanych, dając im tym samym poczucie kontroli nad ucieleśnionym „ja”. Interpretacja przywołanych wyżej motywów każe dostrzec w podwieszaniu kolejny etap przejmowania kontroli nad własnym ciałem jako swego rodzaju projektem. Ta samokontrola „określa istotę doświadczenia podmiotowości: odpowiedzialna za siebie jednostka może sama sobą zarządzać" (Jacyno 2007: 179). Zacieśniając związek między ciałem a tożsamością, badani deklarują przejmowanie coraz większej osobistej odpowiedzialności za własną cielesność.

\section{PRACA NAD CIAŁEM}

Podwieszanie ciała nie jest jednak traktowane przez badanych jako rodzaj poświęcenia dla swojego ,ja”. To raczej element stałej pracy nad ciałem, która ma przebiegać zgodnie z tym, jak rozwija się ich koncepcja siebie:

W tamtym czasie przechodziłam swego rodzaju zmianę. Ja wychodzę z założenia, że ludzie co jakiś czas stają się zupełnie innymi ludźmi. Ja ciągle czegoś poszukuję i chcę się rozwijać. Na pewno w podwieszaniu poszukiwałam swojej tożsamości. Ja w ogóle mam gen poszukiwania nowości. 
Strasznie lubię wyszukiwać sobie takie rzeczy i sprawdzać siebie, robić rzeczy, na które innych nie stać. Ale nie na zasadzie konkurencji, bo ja tak naprawdę o swoim podwieszeniu nikomu nie powiedziałam, nikomu się nie chwaliłam. Ja to zrobiłam tylko i wyłącznie dla siebie (K, 27 lat).

Można powiedzieć, że zmierzam do doskonałości, która jest nieosiągalna, ale do możliwie jak najlepszego kontaktu umysł-ciało, do rozwoju, na ile się da. Na początku to było też przykrycie innych niedoskonałości, na pewno. Na początku miałem multum kompleksów i byłem jednak bardzo słaby psychicznie. Zawsze byłem taki... no nawet troszkę wyśmiewany za to, że nie umiałem się odnaleźć po prostu. Jak wyprowadziłem się z domu rodzinnego, to zacząłem tę zmianę, a suspension potem ją dużo przyśpieszyło. Staram się pracować nad ciałem. I to jest też takie szukanie samego siebie (M, 23 lata).

Podwieszanie bywa poprzedzone znaczącą zmianą w życiu jego uczestników, jak choćby zmianą statusu społecznego czy taką, która wiąże się z przekroczeniem pewnych granic terytorialnych. Podwieszanie okazuje się reakcją na te zmiany, ale też bodźcem wyzwalającym zmiany mające dopiero nastąpić. Dla niektórych z badanych podwieszanie ciała wiązało się ściśle z realizowaną rolą zawodową i w tym kontekście stanowiło ważny element rozwoju:

Był to dla mnie najlepszy moment dla dalszego rozwoju. Ja już prawie sześć lat pracowałam w zawodzie piercera, miałam już za sobą doświadczenie w pracy w studiu tatuażu. Rozwijałam się już w tej swojej wąskiej dziedzinie, bo najpierw uczyłam się przekłuć standardowych, potem powierzchniowych, potem implantów. W pewnym momencie okazało się, że jestem jedyną osobą na Śląsku, która zajmuje się intymnym piercingiem damskim. I podwieszanie to była naturalna kolej rzeczy. Osiągnęłam pewien poziom i tak naprawdę chciałam robić coś dalej. O ile nie pociągają mnie modyfikacje zakrawające o interwencje chirurgiczne, jak właśnie robienie implantów transdermalnych czy subdermalnych, rozcinanie języka, to podwieszanie się i podwieszanie innych było kolejnym etapem. Poprzez podwieszanie chciałam się dowartościować i utwierdzić się w swoim miejscu w branży modyfikacji ciała (K, 28 lat).

Badani wyrażają się poprzez swoje ciało. W ciele znajduje odzwierciedlenie całe ich życie, a przede wszystkim to, co zmienia się w nich samych. Ciało w swoich licznych przekształceniach ma być miejscem, w którym urzeczywistnia się i uzewnętrznia ich ,ja”. I odwrotnie, poprzez skierowanie na ciało odpowiednich praktyk badani chcą pracować nad niektórymi cechami określającymi ich tożsamościowo:

Ciężko mi to określić, ale ja bym powiedziała, to może banalnie zabrzmi, ale podwieszanie było dla mnie przejściem do etapu samodzielności. Sama decyduję, że tego chcę i to robię. Podwieszanie miało mi dać tę samodzielność (K, 27 lat).

Moim motywem była chęć przezwyciężenia siebie, wzmocnienia swojej wiary w siebie (K, 21 lat).

Przez podwieszanie dążę do większej harmonii z ciałem i do tego, żeby rozwijać w sobie umiejętność radzenia sobie w sytuacjach stresowych (M, 23 lata).

Choć charakterystyczne dla tej grupy badanych dekoracje skóry są tym, co w dużej mierze stanowi o wartości ciała, praca nad nim nie dotyczy wyłącznie jego powierzchni. 
Badani poddają swoje ciała reżimom dietetycznym i kondycyjnym, które określają również jako konstytutywne dla ich tożsamości. Zaniedbanie w którymkolwiek z obszarów pracy nad ciałem rodzi tożsamościowy niepokój. „Identyfikując się ze swoimi ciałami, ludzie przejęci są tym, że jeśli nie będą nad nimi nieustannie pracować, utracą siebie" (Bauman 1992, za Wieczorkiewicz 2000: 199). Tłem dla tak sprawowanej kontroli nad ciałem jest ta konsekwencja nowoczesności, którą jest pozostawanie jej samej poza kontrolą (Giddens 2008). W tym kontekście ciało ludzkie staje się ostatnim bastionem naszej kontroli. „Jako takie wydaje się, że dostarcza mocnych podstaw, na których można zbudować stabilne i sensowne poczucie siebie we współczesnym świecie" (Shilling 2010: 227). Bez wątpienia staje się to również doświadczeniem badanych. Stosowana przez nich ucieczka w ciało pokazuje, że to właśnie ono ma być fundamentem, na którym chcą budować swoje poczucie tożsamości. Wraz z kolejnymi modyfikacjami rozwijają umiejętność kontrolowania własnej cielesności, co przekonuje ich o nieograniczonych wprost możliwościach ciała, a w konsekwencji o większej kontroli nad własnym życiem i poszerzeniu osobistego sprawstwa. Zmiany będące rezultatem ciągłej refleksji i pracy nad ciałem mają pomóc badanym w znalezieniu odpowiedzi na najważniejsze tożsamościowe pytania.

\section{ODMIENNE STANY ŚWIADOMOŚCI}

Niektórzy z badanych w praktykowaniu podwieszania ciała poszukiwali nade wszystko niezwykłych stanów świadomości. Pragnienie doświadczenia takich przeżyć od dawna towarzyszyło gatunkowi ludzkiemu. Zmienianie stanów świadomości czy dostąpienie innego jej wymiaru może odbywać się za pomocą różnych metod, do których oprócz wprowadzania do organizmu substancji psychoaktywnych zalicza się praktyki religijne i modyfikacje ciała. Istotne w kontekście tej motywacji podwieszanych okazuje się to, że badanym znane już były doświadczenia z osiąganiem odmiennych stanów świadomości za pomocą wymienionych wyżej sposobów. O pragnieniach doznania poprzez podwieszanie ciała zmysłowej transcendencji traktują przywołane poniżej wypowiedzi:

Poszukuję innych stanów świadomości i to jest powód mojego podwieszania i cel. Wiedziałam, że odkryję takie miejsca, gdzie jeszcze mnie nie było w sobie. I tak było... (K, 27 lat).

Chciałbym przeżyć taki stan zmienionej świadomości, ale jeszcze do tego nie doszedłem. Chciałbym, bo wiem, że można ze świadomością zrobić niesamowite rzeczy. Taki stan można tylko osiągnąć, robiąc długie podwieszanie, bawiąc się jakby bardzo intensywnie, długo. $Z$ tego, co wiem, w pewnym momencie po prostu organizm faktycznie odłącza się i traci się wzrok, słuch, takie jakby jest zejście organizmu do omdlenia. Ale jeszcze do tego nie dotarłem, a chciałbym i to jest mój motyw. Chciałbym to przetrenować, tak do końca, na ile ciało mi pozwoli się od siebie uwolnić (M, 23 lata).

Badani, na co dzień pogrążeni we własnym ciele, stosujący wspomnianą ucieczkę w ciało, w akcie podwieszenia chcą od tegoż samego ciała uciec. Ale czym właściwie ma być ta zamierzona ucieczka i jak należy ją rozumieć? Nie chodzi w niej bynajmniej wyłącznie 
o osiągnięcie stanu bezcielesności równoznacznego z poczuciem uwolnienia się od wszelkich ograniczeń i słabości ciała, z których najistotniejszym jest w tej sytuacji ból. Badanym chodzi o doświadczenie czegoś znacznie głębszego. To rodzaj ucieczki do wewnątrz ciała, jakże różnej od codziennej ucieczki w ciało, której sensem jest przede wszystkim koncentracja na jego zewnętrznej powłoce. Tego rodzaju motywacja świadczy o tym, że badani w swoim sposobie używania ciała odrzucają styl lustrzany, którego istotą jest zatopienie się wyłącznie w powierzchni ciała (Frank: 1991: 61). Chcą i próbują dotrzeć do jego „wnętrza”, które ma stać się im dostępne właśnie w akcie podwieszania. Ucieczka do wewnątrz ciała, znana ze średniowiecznych reżimów religijnych (Bynum 1987), w interpretacji badanych ma być szczytowym momentem wejścia w związek z ciałem i najintensywniejszym jego doświadczeniem. A skoro cielesność jest kluczowym elementem tożsamości, owa ucieczka do wewnątrz ciała stwarza szansę na odnalezienie swojego prawdziwego ,ja”, co badani wiążą właśnie z dostąpieniem wyższego poziomu świadomości:

Ten stan, w którym się jest, jest taki pseudonarkotyczny. Jest się na takim naturalnym haju, ludzki mózg całkiem inaczej pracuje w takich sytuacjach. [...] Jestem wtedy bardziej świadom swojego ciała, skupiam się na ciele, odcinam te zmysły, które postrzegają to, co się dzieje wokół, skupiam się tylko i wyłącznie na ciele. Do tej pory nie odnalazłem jeszcze nic, co by mi tak spasowało, jeśli chodzi o te przeżycia. Każde podwieszanie traktuję jako samodoskonalenie własnego „ja" (M, 23 lata).

Nie po to się to robi, żeby bolało tylko, tylko dla osiągnięcia zupełnie czegoś innego. Trzeba być naprawdę pewnym, że tego się chce, bo to naprawdę może odmienić na zawsze. To jest taki bliski kontakt ze swoim ,ja”, to jest tak niesamowite uczucie... Podwieszanie jest dla mnie sposobem bycia ze sobą tak blisko i w tak bardzo ekscytujący sposób. Przed podwieszeniem miałam ochotę rozpłakać się ze szczęścia. Ja się kompletnie nie bałam, byłam szczęśliwa. Branie narkotyków czy czegoś innego to jest tylko ułuda, a w tym momencie jest się z samym sobą, z samym sobą i... to co się wytwarza, te emocje... to jest prawdziwe. Wiem, kim jestem (K, 27 lat).

A zatem w trakcie podwieszania dosłowna ucieczka od ciała nie jest możliwa, wszak ciało jest tutaj narzędziem, dzięki któremu udaje się osiągnąć ów pożądany stan wyższej świadomości. Jego sensem staje się afirmacja „wnętrza”, aż po zupełne w nie wycofanie. Warte podkreślenia jest też to, że badani pozostają tutaj mocno świadomi swojego ciała. Zdają się kontrolować wrażenia zmysłowe przez nie odbierane poprzez zamknięcie się na te, które pochodzą z otoczenia zewnętrznego, przy równoczesnym otwarciu się na te, które docierają z wnętrza organizmu. A. Giddens, pisząc o świadomości ciała, którą traktuje jako „sposób budowania zróżnicowanej jaźni”, konstatuje: „Takie świadome doświadczanie własnej cielesności jest środkiem prowadzącym do konsolidacji »ja« jako zintegrowanej całości, pozwalającej powiedzieć »oto jestem«" (2012: 111).

Opisana przez badanych ucieczka do wewnątrz ciała może być interpretowana jako próba poszukiwania bądź przybliżenia się do sacrum tkwiącego w ciele. Émile Durkheim, odnosząc się do rytualnych praktyk cielesnych, pisze, że „organizm ludzki kryje w swoich głębinach jakiś pierwiastek sakralny, który wyraźnie się uzewnętrznia w pewnych okolicznościach" (2010: 120). Jeśliby nawet uznać, że w trakcie podwieszenia ciała na hakach dochodzi do 
uzewnętrznienia tego pierwiastka, to warto tutaj zaznaczyć, że nie posiada ono wymiaru integracji społecznej i w żaden sposób nie spaja społeczności osób skupionych wokół tej praktyki cielesnej. Pragnę w tym miejscu podkreślić mocno indywidualistyczny charakter podwieszania.

Zmęczeni i znużeni codzienną rutyną podwieszani poszukują doznań i wrażeń, które pozwalałyby choć na chwilę od niej uciec. Oczekują przeżycia czegoś niesamowitego, czegoś, co można by nazwać doświadczeniem eskapistycznym. To ostatnie miałoby rozciągać się nawet na samą sytuację podwieszania, w której badani chcieliby oderwać się także od tych ludzi, którzy ich otaczają. Dlatego w tym szczególnym rodzaju motywacji, której sensem jest pragnienie osiągnięcia wyższego poziomu świadomości, uwzględniona musi być troska o należyty przebieg samego aktu podwieszania. Badani, którzy zakładali sobie taki właśnie cel, zastrzegali, że w trakcie podwieszenia jawiącego się tutaj jako rodzaj cielesnej celebry, chcą pozostać sami ze sobą. Od momentu, kiedy ciało osoby podwieszanej zostaje uniesione do góry, aż do chwili, w której ona sama wyraźnie zasygnalizuje chęć zakończenia tej praktyki, dostępu do niej bronią wyznaczeni do tego ludzie. Chodzi tutaj nie tylko o nienaruszanie terytorium cielesnego odnoszącego się do skóry i ubrania, które Erving Goffman nazywa „powłoką” (the sheath), ale też ochronę dostępu do ,przestrzeni osobistej” (personal space) podwieszanych (2011: 59 i 49).

\section{DUCHOWO-CIELESNA EKSTAZA}

Podwieszanie ciała, które nie jest w zasadzie formą jego modyfikowania, uważane jest za rodzaj zabawy z ciałem. Wśród badanych znaleźli się tacy, którzy udział w seansie suspension wiązali nade wszystko z chęcią zmysłowego doświadczenia swojej cielesności, czymś, co można by nazwać duchowo-cielesną ekstazą. W ich oczekiwaniach porównywana była ona z przeżyciami mistycznymi i doznaniami orgazmicznymi. Badanym towarzyszyły w tej motywacji fantazje związane z rozumieniem ciała głównie jako źródła przyjemności. Podwieszenie miało być tym krokiem, dzięki któremu fantazje te mogły zostać urealnione. Zdarzało się, że motywy te budowali po obserwacji podwieszania innych osób, jakby doświadczając w tej praktyce cudzej cielesności:

Uczestniczyłem w takim zamkniętym pokazie podwieszania, widziałem targające emocje... Widziałem chłopaka, który walczył ze swoim ciałem, miał słabą krzepliwość krwi, był podwieszany, ta krew, kolokwialnie mówiąc, ,sikała”, ale on nie chciał zrezygnować, bo miał taki cel. Towarzyszyła mu dziewczyna. I nagle po takiej godzinnej walce ze sobą, tych ludzi, którzy go podwieszali, idzie do góry! Ta dziewczyna go łapie, on się śmieje, dziewczyna płacze, widać, że tak jakby mnóstwo emocji między nimi współgra. Czy inny chłopak... Musiał szybciej wyjechać, więc prosił, czy byłaby szansa podwiesić go wcześniej. Słuchał hiphopowego utworu, te haki były mu wbijane, a on się świetnie bawił, właściwie tańczył. To jest ogrom emocji i trudno coś oglądać i nie spróbować. Nie można poznać tego, jeśli się nie spróbuje. Istotą tego jest uczestnictwo w tym (M, 28 lat).

Jakaś siła mówiła mi, żebym to zrobiła. Najważniejszy motyw to chyba te emocje, które czułam, oglądając takie rzeczy, które skłoniły mnie do tego, żeby samej to poczuć o stokroć mocniej. Widziałam, jak ludzie to robią, i czułam wtedy ogromną ciekawość i taką ekscytację od samego 
patrzenia na to. To wywoływało u mnie tak silne emocje, że doszłam do wniosku, że kiedy ja tam będę, to przeżyję coś naprawdę niesamowitego (K, 27 lat).

Badani, którzy byli obserwatorami podwieszeń innych osób, czuli się wzbogaceni estetycznie tym, co zobaczyli. W podwieszonym ciele dostrzegali piękno i erotyzm. Doświadczali stanu radosnej euforii, który w wyraźny sposób wpłynął na budowanie motywacji własnego udziału w podwieszaniu. Było to na tyle silne przeżycie, że od tego czasu sukcesywnie zmierzali do inicjacyjnego podwieszenia. Według relacji badanych, emocji i myśli narosłych wokół tego zamiaru nie zdołali już wygasić i zatrzymać:

Zawładnęło to moją wolą w pewnym momencie i nie mogłam przestać o tym myśleć. I podwiesiłam się po raz pierwszy. Ten pierwszy raz był najfajniejszy. Najmilej go wspominam. Czułam się po tym przez miesiąc czasu na takim naturalnym haju non stop. Byłam taka otwarta na wszystko (K, 21 lat).

Motywacją do dalszego podwieszania ciała staje się chęć powtórzenia tych przyjemnych doznań, które udało się osiągnąć za pierwszym razem. Badani mówią tutaj o swego rodzaju przymusie przystąpienia do kolejnych podwieszeń, który powstaje pod wpływem emocji i wrażeń doświadczanych nie tylko w trakcie samej praktyki, ale także na długo po jej zakończeniu. To, co definiowane jest przez podwieszanych jako korzyść z udziału w tej praktyce cielesnej, ma polegać na utrzymującym się po podwieszeniu endorfinicznym nastroju, subiektywnym poczuciu szczęśliwości, wolności i mającym się z nich wywodzić otwarciu na ludzi:

Po pierwszym podwieszeniu już wiedziałam, że to jest takie pozytywne uczucie, taka adrenalina i takie swego rodzaju wyzwolenie, że chciałam to powtórzyć. Ja na przykład żadnego bólu nie czułam (K, 25 lat).

Już wiedziałam, jaki stan mogę osiągnąć, bo byłam już podwieszana. Byłam już raz podwieszaną i było mi tak dobrze i przyjemnie i to spowodowało, że drugi raz się na to zdecydowałam. Ja myślę, że to może być rodzaj uzależnienia później, bo teraz cały czas myślę, żeby częściej to robić (K, 25 lat).

Niewątpliwie, badani chcą w podwieszaniu zaspokoić swoje zmysłowe pragnienia, chcą dogodzić ciału rozumianemu jako fizyczne ,ja”. Ale przyjemne doznania przeżyte w trakcie podwieszenia ciała mają ułatwiać im także późniejsze działanie. $\mathrm{Ci}$, którzy tego doświadczyli, twierdzą, że podwieszają się, by lepiej sobie radzić w życiu:

Bardzo fajną rzeczą, która już jest po, jest niesamowita dawka endorfin i to jest motyw moich kolejnych podwieszeń. Jak już wyjmą haki, jak już się wraca z Wrocławia, siedzi się w pociągu i się już jest w tej Warszawie i trzeba iść do pracy, to wszystko jest jakieś takie inne. Nie wiem, po prostu zupełnie inaczej się patrzy na świat, jakaś taka dawka pozytywnych wrażeń, taki bardzo duży ładunek pozytywnych emocji. Po prostu wtedy wiem, że ze wszystkim dam radę (K, 23 lata).

Podwieszanie ciała można zatem uznać za jedną z Foucaultowskich „technik siebie”, dzięki którym możemy „dokonywać, za pomocą własnych środków bądź przy pomocy innych, pewnych operacji na własnych ciałach oraz duszach, myślach, zachowaniu, sposobie bycia, 
operacji, których celem jest przekształcenie siebie tak, by osiągnąć pewien stan szczęścia, czystości, mądrości, doskonałości czy nieśmiertelności” (Foucault 2000: 249). A skoro tak istotnym motywem praktykowania podwieszania ciała jest poczucie przyjemności zmysłowej, znów przyjdzie nam zatrzymać się przez chwilę na kwestii bólu. W przywołanych powyżej motywach podwieszania ból nie jest postrzegany jako źródło owej przyjemności. Nie ma w nich miejsca na ból. Badani nie chcieli go doświadczać. Świadome przeżywanie bólu nie było ich potrzebą. Według relacji badanych, gdyby tylko można, chcieliby go uniknąć. Samemu bólowi nie przypisuje się tutaj żadnego szczególnego znaczenia. Z pewnością nie traktuje się go w kategoriach poświęcenia.

Jako że podwieszanie ciała nie jest formą jego modyfikacji, nie może w nim chodzić o budowanie tożsamości badanych na podstawie ich wyglądu. W przypadku tej konkretnej praktyki chodzi raczej o budowanie indywidualnej tożsamości opartej na takich aspektach cielesności jak ,zmysłowość”, która, jak pisze A. Giddens, „odnosi się do sposobu przyjmowania przyjemności i bólu” (2012: 138).

\section{PROMOCJA NEOPRYMITYWISTYCZNEGO NURTU PODWIESZANIA CIAŁA}

Społeczno-kulturowy charakter motywów podwieszania ciała wiąże się z promowaniem neoprymitywizmu i rytuałów z nim związanych. W badanej grupie znalazły się osoby powiązane z subkulturą body modification ${ }^{4}$ i na tyle zafascynowane rytuałami północnoamerykańskich społeczności plemiennych, że dostrzegają w nich szansę na realizację własnych specyficznych potrzeb:

Uważam, że wszystkie te pradawne rytuały jednak miały coś w sobie, a współczesny człowiek pozbawiony tych rytuałów zatracił mnóstwo instynktów, które pierwotni ludzie zdobywali przez tego typu doświadczenia. I tego mi brakuje trochę w życiu współczesnym. To jest początek mojej przygody ogólnie z takimi rytuałami, bo to są bardzo mało popularne rzeczy, a kilku rzeczy chciałbym spróbować (M, 23 lata).

Jako mała dziewczynka byłam harcerką w drużynie, która miała puszczańskie korzenie. W każdym razie bawiliśmy się w Indian, a suspension jest zaczerpnięte od Indian Ameryki Północnej. Jako jedną ze sprawności harcerskich mieliśmy... coś związanego z byciem Indianinem. Jedną ze sprawności zdobywaliśmy, tańcząc właśnie w koralu słońca, tyle, że bez haków, bez niczego, to była taka zabawa. I to w jakimś stopniu wydaje mi się, że skierowało mnie na taki tok myślenia (K, 21 lat).

Warto w tym miejscu zatrzymać się na kwestii deklarowanych przez badanych związków z kulturą modyfikacji ciała oraz ich motywacyjnych odwołań do tradycyjnych form podwieszania obecnych w plemiennych kulturach Indian Ameryki Północnej. Tym badanym, którzy identyfikują się z ruchem ,współczesnych prymitywistów”, zależy na stworzeniu świadomości społecznej dotyczącej dziedzictwa oraz bogactwa kulturowego powiązanego z modyfikacjami

4 Za jej punkty skupienia można uznać magazyn internetowy „BME - Body Modification Enzine” oraz forum internetowe: http://forum.bodymodifications.pl/. 
ciała i obrzędami skierowanymi na ciało. Słuszne i potrzebne wydaje się w tym miejscu użycie terminu „dyfuzja kulturowa” jako pojęcia używanego na „przestrzenne rozchodzenie się lub przenoszenie się elementów kultury (cech, instytucji, wzorów, wątków, tematów, obyczajów) w drodze zapożyczenia”, co odbywa się między zbiorowościami kulturowo odmiennymi (Nowicka 2004: 105). Na popularyzatorski aspekt podwieszania w jego nurcie neoprymitywistycznym w sposób szczególny zwracają uwagę studenci i absolwenci etnologii i antropologii kulturowej, którzy znaleźli się w badanej grupie. To oni najbardziej starają się o przywrócenie podwieszaniu sensu duchowych poszukiwań znanego z najstarszych form tej praktyki ${ }^{5}$. Ta grupa badanych w sposób niezwykle drobiazgowy dba także o rytualną oprawę podwieszania, które każdorazowo jest dla nich wielkim wydarzeniem. Inspirację czerpią z opisanego w trzeciej części niniejszego tekstu obrzędu zwanego tańcem słońca, kultywowanego przez większość plemion Indian Prerii. Dlatego oprócz nawiązującej do niego scenerii podwieszaniu zawsze towarzyszy muzyka. Odwołując się do pierwotnych pragnień i potrzeb człowieka, w praktykowaniu podwieszania ciała dostrzegają szansę na samorozwój, wzrost własnej duchowości i artystyczną ekspresję:

Jezus Chrystus też przez swoją cielesność wydobył swoją duchowość. A z nas nagle próbuje się zrobić takich oszołomów, cyrkowców i przyznam się, że temu się też chcę przeciwstawić poprzez podwieszanie, pokazując tę cielesność inaczej. [...] Ja jestem trochę niespełnionym artystą. Podwieszanie daje mi możliwość spełnienia się artystycznego. Myślę, że za późno jest dla mnie, abym nauczył się rzeźbić, może za późno jest dla mnie, abym zaczął malować piękne obrazy. Ale przez podwieszanie wyrażam się artystycznie (M, 28 lat).

Ja w ogóle mocno zajmuję się antropologią, jakimiś sprawami społecznymi. Studiowałem na studiach antropologicznych, studiowałem historię, więc interesowałem się tym z naukowego punktu widzenia. No i też przebywam w kręgu modyfikacji ciała, w takim kręgu jak body piercing czy tatuaż też jestem. Uczestniczę w tym od pewnego czasu. [...] I ja uważam, że rozmawianie o cielesności w kontekście duchowości, że ciało jest połączone z duchem, w Polsce w ogóle nie istnieje. W ogóle w Polsce temat cielesności jest albo przedstawiany w kontekście pornograficznym, albo czysto konsumpcyjnym - reklamowo-plastikowym, albo jest zamiatany pod dywan. Podwieszanie jest swego rodzaju nowością. Chciałem pokazać to innym ludziom. Zacząłem się na tyle silnie identyfikować z tą kulturą, że chciałem ją rozwijać, chciałem ją przekazywać dalej (M, 28 lat).

W powyższych relacjach dostrzegalny jest pewien rodzaj buntu wobec tych kulturowych i społecznych konwencji, w jakich obecnie ukazywane jest ciało. Dlatego dla badanych podwieszanie ma być okazją do wyzwolenia ciała z jego współczesnych ujęć i definicji. Dochodzą

5 O ważności duchowego aspektu modyfikacji cielesnych świadczy choćby to, że osoby je praktykujące założyły kościół - The Church of Body Modification. Na jego stronach internetowych czytamy, że misją tego międzywyznaniowego kościoła jest ,edukowanie, inspirowanie i pomoc w prowadzeniu naszych członków duchową ścieżką modyfikacji ciała. Celem praktykowania cielesnych modyfikacji ma być zjednoczenie umysłu, ciała i duszy, by połączyć się z naszą siłą wyższą" (The Church of Body Modification, 28.10.2015). Z dalszej lektury zawartości tej witryny dowiemy się też, że członkowie The Church of Body Modification wyznają przekonanie o tym, że ciało jest ich własnością i w związku z tym przysługuje im prawo do jego modyfikowania. Samo ciało traktują jako główny element konstytuujący i definiujący tożsamość człowieka. 
w tym miejscu do głosu neoprymitywistyczne odwołania do założeń body art. Ci badani, którym zależy właśnie na tym kierunku rozwoju podwieszania, chcą pokazywać ciało wzbudzające szok, strach, wstręt i odrazę. Takie przedstawienia ciała spełniają niewątpliwie funkcję sztuki, bo nie tylko przyciągają uwagę, ale też drażnią i skłaniają do refleksji. Ciała osób podwieszanych, używane na sposób komunikatywny, pozostają diadyczne, otwarte na interakcje z innymi (Frank 1991: 51, 89). Ciało zawieszone na hakach przebijających skórę, uniesione w górze, rodzące skojarzenia $\mathrm{z}$ ciałem powieszonego samobójcy, a w dodatku brodzące krwią, musi być uznane za dewiacyjne. Ale i z widokiem takiego obscenicznego ciała, zdaniem badanych, powinniśmy być konfrontowani i oswajani. Ma to być sensem rozwoju praktyki podwieszania ciała wpisanej w artystyczną przestrzeń. Oto jak projektuje go jeden z badanych:

Dorastam do tego, myślę, żeby samodzielnie, na swoich zasadach się podwieszać. Mnie fetyszyzm nie pociąga. Pociągają mnie rzeczy czysto performerskie, gdzie podwieszanie jest wykorzystywane jako forma protestu czy happeningu na ulicy. Ja bardziej chciałbym zacząć odwoływać się do stricte artystycznych rzeczy. Podwieszanie traci w tym zestawieniu konwentowo-freakowym. Robi się to dla mnie cyrkiem. Wolałbym robić to w takim czysto malarskim ujęciu, żeby zaakcentować pewne rzeczy. Chciałbym nadać temu inny wymiar, spróbować wejść w taki klimat galeriowy, pracować z przekonaniami, wejść w klimat czysto zaangażowanej sztuki. To jest kwestia rozwoju suspension. Chciałbym mieć grupę osób, z którą bym się podwieszał. Bo kwestią artyzmu tego wszystkiego jest przygotowanie do przedstawienia, przedstawienie, wyrażenie czegoś, rozmowa. W takiej grupie artystycznej dziełem sztuki i jakby materią, z którą się pracuje, jest ciało. [...] Chciałem pokazać podwieszone ciało, aby ludzie je zobaczyli, ale nie dla samego zobaczenia, tylko dla przemyśleń, które powinny się tu pojawić. Dlatego chcę to robić nie jako performer - rzeźnik, ale performer - artysta (M, 28 lat).

Badani wpisujący podwieszanie w body art chcą też przywrócić własnemu ciału fizyczność. Mimo że ich ciała posiadają liczne modyfikacje, które nadają im niezwyczajny wygląd, W akcie podwieszania chcą wyeksponować swoją zwyczajną, naturalną cielesność. W przypadku większości pozycji badani przystępują do podwieszenia częściowo nadzy:

To jest wszystko dość specyficzne, bo na podwieszaniu spotykają się często ludzie, którzy w ogóle się nie znają. I tak na przykład obserwowałem, jak jakaś dziewczyna się podwieszała. Uwierał ją stanik, więc bez oporów go zdjęła. I nie ma takich jakby oporów tutaj. Ja nie poczułem się „sperwersowany”, że kobieta zdjęła biustonosz, czy na przykład jak komuś pocieknie krew. Ja sam jestem bardzo chudy, ale rozebrałem się do samej bielizny (M, 23 lata).

Chociaż uważam, że moja pupa jest za duża, to w trakcie podwieszania nie czułam się z tym źle. Było bardzo okay. Nie miałam jakichś problemów, takich kompleksowych, że jestem za gruba, moja ręka jest za gruba, moje plecy to są brzydkie. To zupełnie się wtedy nie pojawiło (K, 23 lata).

W swoim neotradycjonalnym sprzeciwie badani pokazują ciało, które w odsłoniętych partiach pozostaje nieestetyczne. Uwidocznione zostają tutaj także niedoskonałości biologicznego ciała, pojawia się krew, ale też zdarza się, że w miejscach przymocowania haków skóra ulega przerwaniu. Ten występ ciała w dużej mierze pozostaje bowiem nieprzewidywalny. W podwieszaniu nie ma miejsca na skontrolowaną ekspozycję takich części ciała jak kobiece 
piersi czy pośladki. Ich prezencja zostaje całkowicie poza kontrolą osoby podwieszanej, dla której nie liczy się tutaj ani wygląd ciała, ani ubiór. O ile w codzienności podporządkowanej wzorcom okocentrycznej kultury ciało pozostaje dla badanych znaczące właśnie z powodu jego wizerunku, to $\mathrm{w}$ trakcie podwieszenia schodzi on na dalszy plan. Udział w praktyce podwieszania ciała zawiera u tych badanych motywację transgresyjną, wyrażoną chęcią przekroczenia tych granic, które wyznaczyła ciału dominująca kultura. To niewątpliwie kontestacja i odejście od promowanych w mediach wizerunków wyrzeźbionych, seksualnych ciał.

Współczesna praktyka podwieszania ciała staje się też sprzeciwem wobec podporządkowania cielesności regułom hedonistycznej kultury. Nie jest to zresztą w cielesnych doświadczeniach badanych jedyna jego forma. Za jego przejaw można również uznać posiadane już przez nich tatuaże i skaryfikacje, zwłaszcza w kontekście ich trwałego i nieodwracalnego charakteru. To właśnie te cechy najdobitniej wpisują się w „,neotradycjonalny trend” konsumowania ciała - jak nazywa go Marek Krajewski (1997: 20). W swoim sprzeciwie wobec nowoczesnego relatywizmu i niestabilności, badani poszukują wartości nieredukowalnych, w czym pomóc ma im ból doświadczany w trakcie podwieszania ciała oraz jego trwałe modyfikacje. Analizujący motywacje wykonywania tatuażu i skaryfikacji Rafał Drozdowski pisze, że zawierają one w sobie symbolikę bólu i ofiary (2006: 165-169). O ile blizny powstałe w związku z umieszczeniem w ciele każdego z badanych kilku czy kilkunastu haków nie wpisują się w jego obraz na stałe, bo po jakimś czasie zagoją się i znikną, to właśnie element bólu wpisanego w sposób nieunikniony w tę praktykę cielesną nadaje jej antynowoczesnego charakteru. Ucieleśnienie sprzeciwu wobec wartości kultury przyjemności, podobnie jak i jej płynnego i zmiennego charakteru, może być też wyrazem tożsamościowych dążeń badanych. Jak pisze Bryan S. Turner - „,cała rzeczywistość jest społecznie konstruowana na skutek nieukończoności Człowieka, jednak ludzie potrzebują stałych znaczeń i nie mogą żyć w ciągłej świadomości społecznie skonstruowanej i niepewnej natury codziennej rzeczywistości, dlatego zmuszeni są nadać tym niepewnościom stałe znaczenie" (1992: 117). I tak, utrwalone na powierzchni ich ciał tatuaże i skaryfikacje mają sygnalizować stałość dokonywanych przez badanych wyborów i pragnienie osobistej niezmienności. Mają je wyrażać poprzesz negację, rezygnację lub świadomą ucieczkę od konieczności ciągłych zmian i przekształceń ciała, które w wyniku owych trwałych modyfikacji przestają być możliwe. Sam akt podwieszenia ciała traktowany jest natomiast przez niektórych badanych jako szczytowa i ostateczna praktyka cielesna:

Ja w świecie tych modyfikacji ciała generalnie siedzę prawie dziesięć lat. I to jest tak, że ja jakby stopniowo odkrywałem pewne rzeczy, pewne etapy, takie jak podwieszanie. Podwieszanie było dla mnie szokujące. Powoli do tego wszystkiego dochodziłem poprzez pierwszy kolczyk czy później bardziej subtelne gry z ciałem typu zaszywanie ust czy zaszywanie oczu, piercing. [...] W końcu zrobiłem sobie pierwszy tatuaż, potem następne, a jeszcze gdzieś po drodze niewielkie skaryfikacje. I dopiero potem, jak już przebyłem przez tę ścieżkę, nastąpiło to podwieszenie, jakby w tej grupie rzeczy, które można wykonać - rzecz ostateczna. To było na końcu tej drabinki. Dość długo ten proces poszukiwania siebie u mnie zachodził (M, 23 lata). 
W miarę kolejnych przekształceń i praktyk cielesnych badani coraz silniej koncentrują się na ciele jako tym, które spełnia konstytutywną rolę dla ich tożsamości. Dekorowanie ciała tatuażami, znakowanie go skaryfikacjami i inne cielesne modyfikacje w żaden sposób nie nawiązują natomiast do poczucia grupowej tożsamości czy tradycji. Także samo podwieszanie ciała jawi się przede wszystkim jako środek ekspresji tożsamości i przejaw osobistej wolności. W zgromadzonym materiale badawczym nie znaleziono tych przesłanek, które świadczyłyby o tym, że ma ono służyć wyrażaniu tożsamości grupowej i jest niezbędne do przetrwania grup ludzkich. Takie cechy zwykle określały funkcjonalność obrzędów plemiennych (Gennep 2006: 13-14). Całe to zainteresowanie własnym ciałem i transformacyjna praca nad nim stanowi wyraz zaangażowania w kreowanie własnego ,ja"6. „Ciało - według A. Giddensa - w coraz mniejszym stopniu funkcjonuje poza samozwrotną logiką systemów nowoczesności, jako zewnętrzne i »dane«, a w coraz większym stopniu samo jest refleksyjnie mobilizowane" (2012: 20). Skoro podwieszenie ciała traktowane jest przez badanych jako świadectwo ich dojrzałości, udział w nim oznacza zwieńczenie poszukiwań własnej tożsamości i tym samym zaprzestanie dalszych modyfikacji i praktyk skierowanych na ciało.

\section{ZAKOŃCZENIE}

Badania jakościowe, którymi objęto osoby praktykujące podwieszanie ciała, dostarczyły szerokiej wiedzy na temat motywów ich udziału w tej formie zabawy z ciałem. Na podstawie zgromadzonego materiału badawczego można stwierdzić, że w motywacji osób praktykujących podwieszania ciała dominuje perspektywa jednostkowa. W sposób wyraźny akcent położony jest w niej na to, co indywidualne i osobiste. Niezwykle ograniczony jest tutaj społeczny wymiar tej motywacji. I tak, jednym z najmocniej akcentowanych motywów podwieszania staje się dziś nieustająca chęć kreowania, pokazywania i aktualizowania swojej jednostkowej tożsamości. Jest to bez wątpienia motyw przewodni udziału w tej praktyce cielesnej. Poszukiwanie własnej tożsamości, któremu podporządkowane są wszystkie omówione powyżej motywy podwieszania, zasadza się u badanych w dużej mierze na poszukiwaniu określonych praktyk używania ciała.

Motywacja osób decydujących się na podwieszenie własnego ciała jest ściśle powiązana ze sposobem jego praktykowania. U tych badanych, którzy podwieszają się podczas zamkniętych, kameralnych spotkań bez udziału publiczności udział w tej praktyce motywowany jest chęcią poznania własnego ciała, pokonania jego poszczególnych ograniczeń, zarządzania ciałem jako prywatnym zasobem, a także pragnieniem doświadczenia odmiennych stanów świadomości, by ostatecznie osiągnąć coś, co w tej grupie badanych nazywane jest duchowo-cielesną ekstazą. Tym badanym natomiast, którzy praktykują podwieszanie ciała podczas otwartych konwentów z udziałem szerokiej publiczności zależy przede wszystkim na popularyzacji samego podwieszania

6 Do analogicznych wniosków doprowadziły badania Agaty Dziuban poświęcone roli, jaką odgrywa tatuowanie ciała w procesie konstruowania jednostkowej tożsamości (2012: 200-227). 
oraz stworzeniu świadomości społecznej dotyczącej jego duchowego i symbolicznego wymiaru, co wpisuje się w ich neotradycjonalny sprzeciw wobec tych społecznych i kulturowych konwencji, w jakich obecnie ukazywane jest ciało ludzkie. Nie oznacza to jednak, że rodzaj publicznego podwieszenia wyzbyty jest zupełnie indywidualistycznego charakteru, wszak i w nim badani upatrują szansy na samorozwój, wzrost własnej duchowości i artystyczną ekspresję.

Analiza indywidualnych motywów podwieszania ciała w zestawieniu ze sposobem doświadczania przez badanych własnej cielesności nie tylko w trakcie tej praktyki, ale i w codzienności pozwala dostrzec kilka ważnych paradoksów. Po pierwsze, o ile praktykowanie podwieszania ciała można uznać za wyraz przejmowania coraz szerszej kontroli nad własną cielesnością, o tyle już w samym akcie podwieszenia kontrola ta zostaje w dużym stopniu utracona. Po drugie, o ile ciała badanych poprzez liczne przekształcenia wskazują na ich zawłaszczenie przez kulturę, o tyle udział w podwieszaniu ma wyeksponować ich naturalność i fizyczność. Po trzecie, o ile badanym zależy na wspomnianym przywróceniu ich ciałom naturalności w akcie podwieszania, to jednocześnie próbują zanegować ograniczenia tego naturalnego ciała. Po czwarte, o ile podwieszanie ciała ma być protestem przeciwko traktowaniu ciała zgodnie ze wzorcami hedonistycznej kultury, to przecież w motywacji badanych bardzo wyraźny jest wątek czerpania $\mathrm{z}$ tej praktyki zmysłowej przyjemności. Najważniejszy paradoks dotyczy jednak samego podwieszanego ciała, które z jednej strony symbolizuje otwartość, ruch, bo jest ciałem w ciągłym procesie stawania się, z drugiej natomiast swoim wizerunkiem sygnalizuje stałość dokonywanych wyborów i niechęć do zmiany, co każe spojrzeć na nie jako na byt już ukończony. Trudno zresztą jednoznacznie określić stosunek badanych do ich cielesności w kontekście praktyki podwieszania. Ciało w jednostkowym doświadczaniu badanych nie jest na tyle uświęcone, żeby nie można było w nie ingerować, ale to samo ciało poprzez skupienie na nim ciągłej uwagi traktowane jest jako obiekt własnego kultu. Zawsze jednak ciało przekracza granice wyznaczone przez obowiązujące wzorce, wartości i normy, a co więcej, zdaje się przekraczać samo siebie. Jest w znacznym stopniu zmodyfikowane, (nie)estetyczne, ale nade wszystko jest fizyczne.

Przedstawienie motywów praktykowania podwieszania ciała ma przede wszystkim walor poznawczy. Dzięki poznaniu złożonej i mocno zindywidualizowanej motywacji, którą kierują się osoby podwieszające swoje ciała na hakach, praktyka ta może przestać być odbierana jako szokująca i zupełnie niezrozumiała. Praktyka podwieszania ciała spotyka się współcześnie przede wszystkim z zarzutem nieracjonalności. Zamiast dbać o swój wizerunek, podwieszający się mają okaleczać i oszpecać swoje ciała poprzez przekłuwanie, nacinanie i przebijanie hakami. Zamiast czerpać przyjemność z doświadczania zintegrowanego ciała, mają naruszać ciągłość jego powłok, narażając się na doznawanie silnego bólu. Współczesna praktyka podwieszania ciała nie jest jednak pustym rytuałem, ale niesie w sobie określoną treść. I jej sens nie sprowadza się bynajmniej do okaleczenia ciała. Poznanie i zrozumienie motywów praktykowania podwieszania ciała może, w odczuciu autorki tekstu, zapobiec wygłaszaniu pochopnych, ,zdroworozsądkowych” ocen, utożsamianiu tej praktyki z satanizmem i rozkwitem neopogaństwa, a także może przyczynić się do uwolnienia podwieszających się od etykiety autodestrukcyjnych dewiantów. 


\section{BIBLIOGRAFIA}

Atkinson, Michael i Kevin Young. 2001. Flesh Journeys: Neo Primitives and the Contemporary Rediscovery of Radical Body Modification, „Deviant Behavior: An Interdisciplinary Journal" 22: 117-146.

Baudrillard, Jean. 2011. Ameryka, Warszawa: Wydawnictwo Sic!

Bauman, Zygmunt. 1992. Intimations of Modernity, London: Routledge.

Bauman, Zygmunt. 1998. Śmierć i nieśmiertelność. O wielości strategii życia, Warszawa: Wydawnictwo Naukowe PWN.

Bynum, Caroline. 1987. Holy Feast and the Holy Fast. The Religious Significance of Food to Medieval Women, California: University of California Press.

Ciężki, Jakub. 2006. Ciało jako obiekt operacji artystycznej, http://www.miki.hg.pl/pra_zjawisko.php [15.03.2016].

Cyrus, Irene Salome. 1997. Indianie Ameryki Pótnocnej, Kraków: Wydawnictwo Znak.

Drozdowski, Rafał. 2006. Obraza na obrazy. Strategie społecznego oporu wobec obrazów dominujacych, Poznań: Wydawnictwo Naukowe Uniwersytetu Adama Mickiewicza.

Durkheim, Émile. 2010. Elementarne formy życia religijnego. System totemiczny w Australii, Warszawa: Wydawnictwo Naukowe PWN.

Dziuban, Agata. 2012. Ja zapisane na skórze. Tatuowanie ciała jako praca tożsamościowa w indywidualizującym się społeczeństwie polskim, „Przegląd Socjologii Jakościowej” 2: 200-227.

Eliade, Mircea. 1997. Inicjacja, obrzędy, stowarzyszenia tajemne. Narodziny mistyczne, Kraków: Wydawnictwo Znak.

Fenske, Mindy. 2007. Tattoos in American Visual Culture, New York: Palgrave Macmillan US. Foucault, Michael. 2000. Filozofia. Historia. Polityka. Wybór pism, Warszawa - Wrocław: Wydawnictwo Naukowe PWN.

Frank, Arthur W. 1991. For a Sociology of the Body: an Analytical Review, w: Mike Featherstone, Mike Hepworth i Bryan S. Turner (red.), The Body. Social Process and Cultural Theory, London - Thousand Oaks - New Delhi: Sage Publications, s. 36-102.

Gąssowski, Jerzy. 1996. Indianie Ameryki Pótnocnej od początków po wiek XIX, Warszawa: Wyższa Szkoła Humanistyczna w Pułtusku - Wydawnictwo Trio.

Gennep van, Arnold. 2006. Obrzędy przejścia. Systematyczne studium ceremonii, Warszawa: Państwowy Instytut Wydawniczy.

Giddens, Anthony. 2008. Konsekwencje nowoczesności, Kraków: Wydawnictwo Uniwersytetu Jagiellońskiego.

Giddens, Anthony. 2012. Nowoczesność i tożsamość. „Ja” i spoleczeństwo w epoce późnej nowoczesności, Warszawa: Wydawnictwo Naukowe PWN.

Goffman, Erving. 2011. Relacje w przestrzeni publicznej. Mikrostudia porzadku publicznego, Warszawa: Wydawnictwo Naukowe PWN.

Jacyno, Małgorzata. 2007. Kultura indywidualizmu, Warszawa: Wydawnictwo Naukowe PWN. Jakubowska, Honorata. 2009. Socjologia ciała, Poznań: Wydawnictwo Naukowe UAM.

Klesse, Christian. 2000. 'Modern Primitivism': Non-Mainstream Body Modification and Racialized Representation, w: Mike Featherstone (red.), Body Modification, London Thousand Oaks - New Delhi: Sage Publications, s. 15-38. 
Konecki, Krzysztof. 2000. Studia z metodologii badań jakościowych. Teoria ugruntowana, Warszawa: Wydawnictwo Naukowe PWN.

Krajewski, Marek. 1997. Konsumpcja i współczesność. O pewnej perspektywie rozumienia świata społecznego, „Kultura i Społeczeństwo” 3: 3-24.

Musafar, Fakir. 1990. Body Play, w: Adam Parfrey (red.), Apocalypse Culture, Los Angeles: Feral House, s. 104-105.

Nowicka, Ewa. 2004. Świat człowieka - świat kultury. Systematyczny wykład problemów antropologii kulturowej, Warszawa: Wydawnictwo Naukowe PWN.

Posern-Zielińska, Mirosława i Aleksander Posern-Zielińska,. 1977. Indiańskie wierzenia i rytuały, Wrocław - Warszawa - Kraków - Gdańsk: Zakład Narodowy im. Ossolińskich.

Simmel, Georg. 1975. Socjologia, Warszawa: Państwowe Wydawnictwo Naukowe.

Shilling, Chris. 2010. Socjologia ciała, Warszawa: Wydawnictwo Naukowe PWN.

Teplicki, Zbigniew. 1994. Wielcy Indianie Ameryki Pótnocnej, Warszawa: Wydawnictwo Książka i Wiedza.

Turner, Bryan S. 1992. Regulating Bodies. Essays in Medical Sociology, London: Routledge.

Vale, V. i Andrea Juno. 1989. Modern Primitives: An Investigation of Contemporary Adornment and Ritual, San Francisco: RE/Search.

Wieczorkiewicz, Anna. 2000. Muzeum ludzkich ciał. Anatomia spojrzenia, Gdańsk: Słowo/ Obraz Terytoria.

\section{IN SEARCH OF SELF. INDIVIDUAL MOTIVES FOR BODY SUSPENSION}

\section{PRACTISED TODAY IN POLAND}

The paper deals with the practice of body suspension, which is one of the forms of body play, initiated and popularized by the Modern Primitive movement. The empirical basis of the paper is the author's own sociological research focused on the issue of individual motives to practise body suspension. The research sample consisted of people who have experienced body suspension several times $(N=30)$. Since grounded theory methodology was selected as the research strategy, the technique of free-form guided interview was used. The theoretical framework for empirical analyses was demarcated by joint, socio-cultural and at the same individual perspective on body perception, with the latter being the most important because of the chosen research strategy. The following motives for participation of the research subjects in body suspension practice emerged from the collected empirical material: to get to know their own bodies; to overcome the limitations of the body; to exercise the right of ownership of the body; to work with the body; to experience a different state of consciousness; to reach spiritual and corporeal ecstasy; to promote neo-primitivist trend of body suspension. In thus described motives for body suspension, the body appears to be a source of knowledge and experience, place of control, object of ownership, source of pleasure, and above all - the centre of identity.

Keywords: sociology of the body, body suspension, body modifications, motives for body suspension, identity 